\title{
POSSIBILIDADES E LIMITES DA REFORMA CONSTITUCIONAL NA ESPANHA NO CONTEXTO DO ESTADO AUTONÔMICO INTEGRADO NA UNIÃO EUROPÉIA*
}

\author{
FRANCISCO BALAGUER CALLEJÓN**
}

\begin{abstract}
RESUMO: Este artigo analisa as possibilidades e os limites da emenda constitucional na Espanha, que deve ser considerada em seus três níveis constitucionais, num contexto de pluralidade de ordenamentos e de constitucionalismo multinível: europeu, estatal e autonômico. Para tanto, aborda em primeiro lugar a regulamentação da reforma na Constituição Espanhola e as atuais propostas de reforma. Em segundo lugar, considera as reformas estatutárias recentemente realizadas no contexto do Estado autonômico. Por fim, estuda o processo de constitucionalização da União Européia partindo da perspectiva da revisão dos Tratados.
\end{abstract}

PALAVRAS-CHAVE: Emenda Constitucional; Constituição Espanhola; União Européia.

ABSTRACT: This article analyzes the possibilities and limitations to the constitutional amendment in Spain, which should be considered in its three constitutional levels, in a context of plurality of orders and multilevel constitutionalism: European, State and autonomous. In order to do this, the text firstly goes over the regulation of the Spanish constitution's amendment and the current amendment proposals. Secondly, it considers the statutory reforms recently performed in the context of the autonomous State. Lastly, it studies the European Union's constitutionalization process with the treaties' revision as a starting point.

KEYWORDS: Constitutional Amendment; Spanish Constitution; European Union.

SUMÁRIO: 1. Introdução. A reforma constitucional no constitucionalismo multinível; 2. O status constitucional da reforma. A reforma constitucional como instituição nuclear da Constituição normativa; 3. Reforma constitucional e relações entre ordenamentos. O poder de reforma da União Européia e das Comunidades Autônomas; 4. A tendência à fragmentação do poder constituinte; 5 . Necessidades constitucionais da sociedade e reforma constitucional; 6 . A reforma constitucional no nível estatal: propostas de reforma e dificuldades para levá-las à cabo; 7. As reformas no nível europeu e no nível autonômico: o medo ao Direito Constitucional enquanto fator de "estatalização" dos ordenamentos; 8. Conclusões.

SUMMARY: 1. Introduction. The constitutional amendment in the multilevel constitutionalism; 2. The constitutional status of the amendment. The constitutional amendment as the normative constitution's nuclear institution; 3. Constitutional amendment and relationships between orders.

\footnotetext{
* Traduzido do castelhano por Hugo César Araújo de Gusmão

** Catedrático de Direito Constitucional da Universidade de Granada e Catedrático Jean Monnet de Direito Constitucional Europeu
} 
The European Union and Autonomous Communities' amendment power; 4. The tendency to the constitutional power's fragmentation; 5. Society's constitutional necessities and constitutional amendment; 6. The constitutional amendment at State level: amendment propositions and hardships to carry them through; 7. The amendments at the European level and at the autonomous level: the fear of constitutional right as a "statelization" factor of the legal orders; 8 . Conclusions.

\section{INTRODUÇÃO - A REFORMA CONSTITUCIONAL NO CONSTITUCIONALISMO MULTINÍVEL}

Sobre a reforma constitucional enquanto instituição confluem as tensões mais intensas do sistema constitucional. Esta acumulação de tensões é algo lógico caso se leve em conta que a reforma não é só um mecanismo técnico de modificação da Constituição senão também a via através da qual o poder constituinte se integra na ordem constitucional. Um poder constituinte submetido a normas, justamente por meio da regulamentação constitucional da reforma, mas que não deixa, por isso, de invocar os agentes políticos com capacidade para reestruturar o contexto de convivência social suposto pela Constituição. Deste modo, a reforma constitucional adquire uma dupla natureza, porquanto expressa e limita, ao mesmo tempo, o poder constituinte.

Num sistema de pluralidade de ordenamentos, nos quais o poder constituinte se fragmenta, conforme veremos, estas tensões se acumulam, dificultando, as vezes, as reformas necessárias em cada um dos ordenamentos ou dos níveis constitucionais. Esta dificuldade acrescida mostra-se especialmente disfuncional porque um dos principais ensinamentos que nos é oferecido pela análise do sistema jurídico, a partir da perspectiva das relações entre ordenamentos, é o da necessidade de introduzir mecanismos mais flexíveis de reforma das normas fundamentais e de abordar a instituição da reforma com uma mentalidade mais aberta que a tradicional.

Num contexto de pluralidade de ordenamentos, é necessário relativizar algumas das funções da rigidez constitucional. Assim, por exemplo, a excessiva rigidez das normas fundamentais (Constituições e Estatutos de Autonomia, no caso da Espanha) como mecanismo de garantia das minorias, em grande medida, carece de sentido no contexto da União Européia. Pelo contrário, esta rigidez dificulta a realização das reformas necessárias. Porém o adiamento indefinido das reformas não contribui para racionalizar o sistema e produz um efeito acumulativo no qual problemas menores de caráter basicamente técnico acabam por se amplificar e se converter em grandes problemas políticos. Ante esta situação, é necessário promover uma cultura constitucional mais aberta, que não se baseie na sacralização dos textos fundamentaies, mas na sua consideração dinâmica. São as normas que devem estar ao serviço da sociedade e que devem se adaptar para fazer frente às novas necessidades sociais.

Em todo caso, tampouco podemos ignorar que se toda sociedade faz frente a suas necessidades constitucionais mediante a reforma de suas normas fundamentais, quando esta reforma não é possível, em razão da falta de consenso entre os agentes políticos, as necessidades constitucionais têm que ser remediadas mediante acordos ou convenções de caráter para-constitucional ou através da interpretação dos preceitos fundamentais.

Na situação específica da Espanha, apresentam-se circunstâncias particulares que devem ser consideradas. O sistema constitucional espanhol se integra dentro de 
uma pluralidade de ordenamentos ou de um constitucionalismo "multinível” de dimensão européia. ${ }^{1}$ Por constitucionalismo multinível entendemos aqui a interação entre os diversos níveis constitucionais no âmbito europeu. Interação dialética que está gerando um Direito constitucional europeu entendido em dois sentidos: em sentido estrito como Direito constitucional da União Européia e em sentido amplo como Direito constitucional dos diversos níveis constitucionais (europeu, estatal, territorial) na Europa ${ }^{2}$.

No caso da Espanha, no entanto, inexiste, na própria Constituição, um reconhecimento expresso da União Européia (como tampouco do Estado Autonómico). $\mathrm{Na}$ Constituição espanhola não há três ordenamentos jurídicos. Estes três ordenamentos existem na realidade, porém não se encontram na Constituição, na qual só existe um ordenamento jurídico, o estatal. De tal maneira que o motivo pelo qual estes três ordenamentos potencialmente existem e coexistem em nosso território não se deve ao fato de estarem na Constituição senão à remissão que ela faz a possíveis ordenamentos que possam confluir com o estatal através dos procedimentos de descentralização territorial e de configuração do Estado autonômico (Título VIII), bem como dos procedimentos de integração na Europa (artigo 93). Na Constituição, ao invés da União Européia encontra-se previsto um procedimento de possível integração em organizações supranacionais. Tampouco figura o Estado autonômico

${ }^{1}$ Esta expressão “multinível” está gozando de um grande êxito nos últimos tempos em referência à proteção dos Direitos assim como, em geral, à interação entre espaços constitucionais, especialmente em nível europeu. Cfr., sobre o primeiro aspecto, Paola Bilancia, "Las nuevas fronteras de la protección mulinivel de los derechos", Revista de Derecho Constitucional Europeo, $\mathrm{n}^{\circ}$ 6, Junio-Diciembre de 2006, pp. 255-277. URL: http://www.ugr.es/ redce/. Cfr. Igualmente Paola Bilancia e Federico Gustavo Pizzetti, Aspetti e problemi del costituzionalismo multilivello, Giuffrè Editore, Milano, 2004; Antonio D’Atena e Pierfrancesco Grossi, Tutela dei diritti fondamentali e costituzionalismo multilivello. Tra Europa e Stati nazionali, Giuffrè Editore, Milano, 2004. Com caráter geral, cfr. Ingolf Pernice, "Multilevel Constitutionalism and the Treaty of Amsterdam: European Constitution-Making revisited?”, em Common Market Law Review, 36, 1999. Versão eletrônica em http://www.whi-berlin.de/documents/whi-paper0499.pdf, Também partindo da perspectiva específica dos direitos: Ingolf Pernice, Ralf Kanitz, "Fundamental Rights and Multilevel Constitutionalism in Europe”. WHI Paper 7/04, März 2004, http://www.whi-berlin.de/documents/whi-paper0704.pdf.

${ }^{2}$ Cfr. Francisco Balaguer Callejón (Coordinador), Gregorio Cámara Villar, Juan Fernando López Aguilar, María Luisa Balaguer Callejón, José Antonio Montilla Martos, Manual de Derecho Constitucional, Vol. I, Tecnos, Madrid, 2007, Capítulo IX. Não podemos aceitar, no entanto, a idéia de uma interação unidirecional baseada na transferência de legitimação entre os níveis estatais e o europeu, que fez com que alguns autores defendessem a idéia de que já existia uma Constituição européia antes da elaboração do Projeto de Tratado Constitucional: "The question "Does Europe need a Constitution" is not relevant, because Europe already has a "multilevel constitution": a constitution made up of the constitutions of the Member States bound together by a complementary constitutional body consisting of the European Treaties (Verfassungsverbund)", Ingolf Pernice, "Multilevel Constitutionalism and the Treaty of Amsterdam: European Constitution-Making revisited?”, cit., p. 707. Pelo contrário, devemos partir da idéia de que a interação entre os diversos níveis é bidirecional e não só contribui com ganhos de legitimação a determinados níveis, senão também com perdas a outros. Por outro lado, não parece aceitável falar de Constituição Européia antes do Tratado Constitucional (no limitado sentido no qual este termo era aplicável ao Tratado) ou do Tratado de Reforma, o qual podemos considerar equivalente ao Tratado Constitucional enquanto, na verdade, Constituição com nome de Tratado, já que mantém os mesmos conteúdos do Tratado Constitucional. Cfr. a este respeito meu trabalho "La Costituzione europea dopo il Consiglio europeo di Bruxelles : da una Costituzione in forma di Trattato ad una Costituzione con il nome di Trattato”, no prelo atualmente na Itália. O Projeto de Tratado de Reforma, de 23 de julio de 2007, pode ser consultado em: http://www.consilium.europa.eu/cms3_fo/showPage.asp?id=1317\&lang=en\&mode=g. 
na Constituição, a qual não utiliza uma única vez este termo nem identifica qualquer Comunidade Autônoma como tal, limitando-se a estabelecer procedimentos de descentralização territorial.

Temos portanto, um ordenamento jurídico complexo, integrado por três níveis ou espaços constitucionais cujo ponto de conexão é o texto constitucional de 1978, sem que neste texto haja uma integração destes ordenamentos que torne possível, tanto do ponto de vista institucional como do normativo, o cumprimento, por parte da Constituição, de sua função de fator regulador das relações entre ordenamentos. Esta complexidade vai se incrementando com o tempo, por que está submetida a uma evolução dinâmica de difícil previsão.

Com efeito, as Comunidades Autônomas cresceram extraordinariamente do nada, criando um corpo institucional que hoje assume uma grande parte do gasto orçamentário público, ocupa a maior parte dos funcionários e exercita um amplo número de competências que antes eram estatais. Do mesmo modo, a União Européia encontra-se imersa num processo de constitucionalização, de resultado incerto, porém absolutamente necessário para que possa afrontar os desafios que se apresentam num mundo globalizado. A complexidade e o caráter dinâmico dos ordenamentos jurídicos europeu, estatal e autonômico é inevitável. Nos próximos anos possivelmente veremos novas conformações destes âmbitos que exigirão, necessariamente, reformas em todos os seus níveis.

No entanto, estas reformas se realizam com uma considerável dificuldade tanto em nível autonômico como europeu, apresentando-se atualmente como impossíveis no nível estatal, apesar do caráter avançado das propostas do Governo, que deram lugar a diversos estudos promovidos pelo Conselho de Estado e a um Parecer sobre estas propostas ${ }^{3}$.

Nesta exposição analisaremos as possibilidades e os limites da reforma constitucional na Espanha, que deve ser considerada em seus três níveis constitucionais, num contexto de pluralidade de ordenamentos e de constitucionalismo multinível: europeu, estatal e autonômico. Para tanto, abordaremos em primeiro lugar a regulamentação da reforma na Constituição Espanhola e as atuais propostas de reforma. Em segundo lugar, consideraremos as reformas estatutárias recentemente realizadas no contexto do Estado autonômico. Em terceiro lugar, consideraremos o processo de constitucionalização da União Européia partindo da perspectiva da revisão dos Tratados.

Porém, antes de abordar estas questões, convém que nos que nos detenhamos, o mais brevemente possível, em algumas questões teóricas relativas à fragmentação do poder constituinte ${ }^{4}$ num contexto de constitucionalismo multinível com diversidade de espaços constitucionais.

\footnotetext{
${ }^{3}$ Cfr. Francisco Rubio Llorente, José Alvarez Junco (eds.) El informe del Consejo de Estado sobre la reforma constitucional. Texto del informe y debates académicos, CEPC, Madrid, 2006.

${ }^{4}$ Cfr. meu trabalho "El status constitucional de la reforma y la fragmentación del Poder Constituyente", em AAVV, La democracia constitucional. Estudios en homenaje al Profesor Rubio Llorente, Congreso de los Diputados, Tribunal Constitucional, Vol. I, , Madrid, 2002, pp. 99-130.
} 


\section{O STATUS CONSTITUCIONAL DA REFORMA - A REFORMA CONSTITUCIONAL COMO INSTITUIÇÃO NUCLEAR DA CONSTITUIÇÃO NORMATIVA}

\subsection{Reforma constitucional e normatividade da Constituição}

São conhecidas as trascendentais funções que a instituição da reforma desempenha no ordenamento da Constituição normativa. Entre elas a de garantir a própria normatividade da Constituição frente ao legislador ao estabelecer a linha divisória entre o poder constituinte e os poderes constituídos. Com isto se consagra uma divisão jurídica ou externa do poder de tal importância como a divisão política ou interna, que possibilita o controle jurisdicional dos atos do legislador com base nas prescrições constitucionais ${ }^{5}$.

A técnica da reforma alcança esta posição nuclear na Constituição normativa a mercê da teoria do poder constituinte 6 . Ainda que esta teoria careça de contornos muito precisos, desempenhou uma importante função, qual seja, a de estabelecer a diferença entre a natureza do poder que dá lugar à instauração de uma nova Constituição e a dos poderes que podem se manifestar dentro desta Constituição. A partir desta perspectiva, pode-se afirmar que o poder constituinte é um poder político, que carece de limites estritamente jurídicos. Esta ausência de limites não implica que careça de condicionamentos sociais e políticos. Alguns destes últimos podem ser formulados inclusive juridicamente, apesar de que os motivos que assegurarão a vinculação do poder constituinte aos mesmos não sejam os jurídicos.

Uma segunda característica do poder constituinte é seu esgotamento no próprio ato de aprovação da Constituição. Aquelas manifestações que porventura se expressem depois, numa Constituição normativa, não serão mais que poderes constituídos, aos quais a própria Constituição outorga diversas potencialidades normativas, inclusive a de modificação da ordem fundamental, a da reforma da Constituição. Sejam quais forem as faculdades outorgadas, nesta última ordem, aos poderes constituídos, os fundamentos do sistema constitucional nunca serão passíveis de alteração jurídica, mantendo-se nos limites da Constituição. À diferença das fontes que se manifestam dentro da ordem constitucional, regidas por um princípio de inesgotabilidade ${ }^{7}$, a Constituição é uma fonte que se esgota na sua própria produção, pois o poder que lhe deu vida desaparece.

Estas duas características do poder constituinte se correspondem com aquelas que são próprias da soberania ${ }^{8}$. Por um lado, com o caráter político e juridicamente ilimitado do poder soberano; por outro com a inevitável contradição entre o princípio de soberania e a democracia constitucional própria de uma Constituição normativa na

\footnotetext{
${ }^{5}$ Cfr. F. Balaguer, “Notas sobre la estructura constitucional del Estado español”, $R D P, \mathrm{n}^{\circ}$ 32, 1991.

${ }^{6}$ A formulação teórica deste princípio é atribuída usualmente a Sieyés. Cfr. E.J. Sieyes, Qu'est-ce que le Tiers État?, 1789, versão espanhola de Jose Rico Godoy, presente em E.J. Sieyes, ¿Qué es el estado Ilano?, (reimpressão do original de 1950), CEC, Madrid 1988.

${ }^{7}$ Cfr. sobre este princípio de inesgotabilidade, Salvatore Pugliatti, “Abrogazione”, en EdD, Vol. I, 1958, p. 142.

${ }^{8}$ Identificação que, por outra parte, tem uma base histórica. Cfr. E. Zweig, Die Lehre vom Pouvoir Constituant. Ein Beitrag zum Staatsrecht der französischen Revolution, J.C.B. Mohr (Paul Siebeck), Tübingen, 1909.
} 
qual todos os poderes devem estar submetidos ao Direito ${ }^{9}$. A soberania popular só pode ser exercida no momento de aprovação da Constituição, pois só então existe tanto o sujeito (o povo enquanto coletividade homogênea) como o objeto deste princípio (o poder soberano) ${ }^{10}$.

Em todo caso, o fato de que a Constituição não esteja submetida ao princípio de inesgotabilidade das fontes permite diferenciar, enquanto fontes distintas, a Constituição da reforma constitucional. Esta diferenciação descortina respostas para alguns dos questionamentos doutrinários propostos em relação à própria possibilidade da reforma e ao estabelecimento, por meio desta instituição, de limites ao poder de reforma. ${ }^{11}$ É certo que uma fonte não pode estipular, a si mesma, limites que determinem a atividade do poder normativo futuro. Esta tese está correta, porém não é aplicável à Constituição enquanto fonte. Daí que não sejam aceitáveis nem a idéia de que a Constituição não possa determinar sua própria reforma (e, portanto, impor-lhe limites), nem a de que a reforma da Constituição se situe num nível superior à própria Constituição $^{12}$. Ocorre justamente o contrário: é a reforma da Constituição que se situa num nível inferior à própria Constituição e que se submete plenamente (na medida em que intervenha como poder jurídico) à própria Constituição.

O aparente paradoxo lógico é explicado com suma facilidade: o postulado de que uma proposição não pode se referir a si mesma, não é aplicável à reforma da Constituição. Com efeito, a reforma não é uma proposição que se refira a si mesma, por que reforma e Constituição são duas fontes distintas, ambas expressões de uma vontade normativa de natureza diferente, com desigual potencialidade jurídica e submetidas a um regime diverso. A reforma está sujeita a condições jurídicas, a Constituição, só a condições políticas. A reforma é expressão de um poder constituído (constituinte constituído), a Constituição é expressão de um poder constituinte. Somente se privamos a reforma de sua natureza jurídica, convertendo-lhe em poder

\footnotetext{
${ }^{9}$ Cfr. M. Kriele, Einführung in die Staatslehre. Die geschichtlichen Legitimitätsgrundlagen des demokratischen Verfassungsstaates, 1975, $4^{a}$ edición, Westdeutscher, Opladen, 1990 (existe versão espanhola editada por Depalma, Buenos Aires, 1980); C.J.Friedrich, Demokratie als Herrschafts und Lebensform, versão espanhola de C. Zabal, La democracia como forma política y como forma de vida, Tecnos, Madrid, 1961. Cfr. igualmente deste último autor Man and his Government. An empirical theory of politics, versão espanhola de J.A. González Casanova, Tecnos, Madrid, 1968 y Constitutional Government and Democracy, versão espanhola de A. Gil, Instituto de Estudios Políticos, vol. I, Madrid 1975, pp. 60 e passim. Na doutrina espanhola, cfr. Pedro de Vega, La reforma de la Constitución y la problemática del poder constituyente, Tecnos, Madrid, 1984; P. Lucas Verdu, “Comentario al artículo 1 de la Constitución” em Comentarios a las Leyes Políticas dirigidos por O. Alzaga, t. I, EDERSA, Madrid, 1983; e I. De Otto, Derecho constitucional. Sistema de fuentes, Ariel, Barcelona, 1987.

${ }^{10}$ Cfr. F. Balaguer Callejón, “Soberanía popular y democracia en la Constitución española de 1978” RDP, n ${ }^{\circ}$ 27-8, 1988 y Fuentes del Derecho, Tecnos, Madrid, vol. II, 1992, pp. 28 y ss. Mais recentemente em “Constitución y ordenamiento jurídico", em Miguel Carbonell (compilador), Teoría de la Constitución. Ensayos escogidos. Editorial Porrúa/UNAM, México, 2000, pp. 194 y ss.

${ }^{11}$ Cfr. F. Balaguer Callejón, Fuentes del Derecho, vol. II, Tecnos, Madrid, 1992, pp. 37 y ss.

${ }^{12}$ Estas abordagens procedem de A. Ross, e podem ser encontradas nas suas obras, Theorie der Rechtsquellen. Ein Beitrag zur Theorie des positiven Rechts auf Grundlage dogmenhistorischer Untersuchungen, Franz Deuticke, Leipzig/Wien, 1929, pp. 359 ss. y On Law and Justice, 1958, versão espanhola de G.R. Carrio, Editorial Universitaria de Buenos Aires, 1977, pp. 76 ss. Trata-se de uma reformulação da teoria da Norma Fundamental de H. Kelsen, da qual compartilha, no entanto, suas deficiências.
} 
constituinte, poderemos afirmar que se trata de uma fonte que, por ser, então, Constituição, não pode valer jurídicamente como limite às modificações desta mais que se considerada como uma fonte superior. Porém, partindo da teoria do poder constituinte, a aparente contradição que suscita a previsão de procedimentos de reforma constitucional se soluciona facilmente. Com efeito, o poder constituinte se esgota com a aprovação da Constituição, de modo que não há, partindo deste ponto de vista jurídico, qualquer autolimitação de um poder de natureza política que se extingue no preciso instante no qual o poder jurídico (a Constituição) começa a operar.

Os limites constitucionais à reforma não são, em sentido estrito, limites ao poder constituinte, mas expressão de um poder distinto, de natureza jurídica (o poder de reforma), que só intervêm dentro do contexto constitucional. Por outra parte, o poder de reforma não pode ser considerado superior ao poder constituinte nem à própria Constituição, já que a assertiva de que nenhuma fonte pode criar outra de superior valor caracteriza-se como um princípio geral do Direito ${ }^{13}$. Aquilo que o poder constituinte cria na Constituição: a reforma constitucional, têm, ainda que parcialmente, um valor inferior à Constituição, pois deve ser regida pela regulamentação constitucionalmente estabelecida.

\subsection{Poder constituinte e poder de reforma}

Indubitavelmente a distinção entre poder constituinte e poder de reforma tem algo de ficção. Como toda formalização jurídica da realidade, não deixa de indicar uma qualificação de um setor concreto que só adquire sentido partindo de uma perspectiva jurídica. É a partir desta perspectiva que é possível a afirmação de que o poder de reforma se trata de um poder limitado, posto que nada impede, partindo de uma abordagem política, a alteração fundamental da ordem constitucional, pelas vias que se considerem convenientes, por parte aqueles que podem fazê-lo. Se isto ocorre, o poder constituinte terá intervindo novamente, para dar lugar a uma nova Constituição. Porém neste mesmo ato terá se esgotado, até que no futuro uma nova ordem constitucional assome através de um novo poder constituinte. Não há, no entanto, na dialética poder constituinte-poder de reforma, mais “autolimitação” que aquela que se dá na dialética poder constituinte-Constituição. Ao não se admitir a metamorfose do poder constituinte nega-se também a normatividade da Constituição. Admite-se a possibilidade de existência de atos de soberania dentro da ordem constitucional. Não há pois “autolimitação”, senão transformação de um poder ilimitado em outro, juridicamente limitado, não como resultado da vontade do soberano, mas por exigência lógica da conformação democrática da ordem constitucional. De outro modo, caso se parta da teoria da pretendida (e negada) autolimitação do poder constituinte, a ordem constitucional desmorona a partir sua base.

Embora a Constituição Espanhola estabeleça limites formais à reforma, não incorpora limites materiais semelhantes às disposições intangíveis. No entanto, a existência de um duplo procedimento de reforma faz com que os preceitos do

${ }^{13}$ Nehnuma fonte pode criar outras que tenhan uma eficácia maior ou igual a sua. Cfr. G. Zagrebelsky, Manuale di Diritto costituzionale. I. Il sistema delle fonti del diritto, UTET, Torino, 1988, p. 5. Só podem ser criadas novas fontes que tenhan uma eficácia menor que a da fonte que as estabelece. 
procedimento agravado atuem como disposições quase intangíveis para o procedimento ordinário, dado que a reforma não poderá afetar estes preceitos ${ }^{14}$. No mais, também se pode defender a idéia de que existem limites materiais à reforma que derivam da proibição de desnaturalizar a ordem constitucional vigente. A falta de explicitação dos mesmos não obsta sua eficácia jurídica, que se manifesta na impossibilidade de aceitar, sob o regime constitucional vigente, e partindo de uma perspectiva jurídica, determinadas reformas que desfigurem o núcleo essencial da Constituição ${ }^{15}$.

Ora, a questão de se o poder constituinte poderia ou não intervir, sem limites materiais, no ordenamento constitucional espanhol, que deu origem a uma ampla e interessante reflexão doutrinária ${ }^{16}$ é suscetível de ser tratada com uma nova perspectiva caso se leve em conta a interação constitucional entre o âmbito europeu, o estatal e o autonômico. O tema já não é se o poder constituinte pode (no sentido de possibilidade teórica partindo de um ponto de vista jurídico) intervir sem limites materiais sob a Constituição normativa e se esta intervenção deve ser qualificada como "reforma" ou se dá lugar, tecnicamente, a uma nova Constituição. Na realidade, esta pergunta seria respondida mais facilmente se nossa Constituição houvesse estabelecido disposições intangíveis: neste caso ficaria claro que a vulneração destas disposições daria lugar, juridicamente, a uma nova Constituição. O problema agora é se o poder constituinte pode realmente se diferenciar, a partir de uma perspectiva jurídica, do poder de reforma, não pelo fato de que o poder de reforma atue (de fato) sem limites jurídicos, como o poder constituinte, senão pelo fato de que este último não possa atuar sem limites jurídicos como tradicionalmente se pensou. Portanto, o problema não é se o poder de reforma pode chegar a se converter em poder constituinte no plano fático, mas se o poder de reforma pode (como possibilidade jurídica) chegar a se converter em poder constituinte: na verdade, se é possível falar ainda de poder constituinte a

\footnotetext{
${ }^{14} \mathrm{Cfr}$. sobre as implicações suscitadas pela existência deste duplo procedimiento, Pedro de Vega, La reforma constitucional, cit., pp. 151. ss.

${ }^{15}$ Cfr. J. Jimenez Campo, “Algunos problemas de interpretación en torno al Título X de la Constitución”, RDP, n. 7, 1980; Pedro de Vega, La reforma de la Constitución, cit., pp. 151 ss., 219 ss.; com outra abordagem, J. Pérez Royo La reforma de la Constitución, Congreso de los Diputados, Madrid, 1987, pp. 187 ss., 207 ss.; cfr. igualmente F. Balaguer, "Derechos fundamentales y Constitución normativa” em AA.VV., Jornadas de Estudio sobre Introducción a los Derechos Fundamentales, DGSJE, Vol. I, Madrid, 1989 y F. Balaguer, Fuentes del Derecho, vol. II cit., pp. 42-3.

${ }^{16}$ Cfr. P. de Vega, La reforma constitucional y la problemática del poder constituyente, cit.; I de Otto, Derecho constitucional. Sistema de Fuentes, cit.; J. Jimenez Campo, "Algunos problemas de interpretación en torno al Título X de la Constitución”, $R D P$, n. 7, 1980; M. Aragón, Constitución y Democracia, Tecnos, Madrid, 1989; J. Pérez Royo, La reforma de la Constitución, cit.; F. Balaguer Callejón, Fuentes del Derecho, vol. II, cit.; B. Aláez Corral, El problema de los límites materiales a la reforma de la Constitución Española de 1978, CEPC, Madrid, 2000. e do mesmo autor, "Soberanía constitucional e integración europea", cit; F.J. Bastida, "La soberanía borrosa: la democracia", Fundamentos, n. 1, Oviedo, 1998; M. Carbonell, Constitución, reforma constitucional y fuentes del derecho en Mexico, Editorial Porrúa-UNAM, México, 1998; M.Contreras, "Sobre el Título X de la Constitución Española: de la reforma constitucional”, Revista de Derecho Político, n. 37, 1992; J.L. Requejo, "El poder constituyente constituido: la limitación del soberano", Fundamentos, n. 1, Oviedo, 1998; S.A. Roura, La defensa de la Constitución en la historia constitucional española, CEPC, Madrid, 1998; J. Ruipérez, J.: “Algunas consideraciones sobre la reforma constitucional”, Revista de Estudios Políticos, 75, 1992.
} 
partir da perspectiva com a qual este tradicionalmente se diferenciou do poder de reforma: a sua insubmissão à limites jurídicos.

Em definitivo, trata-se de analisar a incidência da progressiva fragmentação do poder constituinte sobre a tradicional relação entre poder constituinte e poder de reforma, aspecto sobre o qual nos deteremos mais adiante.

\section{REFORMA CONSTITUCIONAL E RELAÇÕES ENTRE ORDENAMENTOS - O PODER DE REFORMA DA UNIÃO EUROPÉIA E DAS COMUNIDADES AUTÔNOMAS}

Os procedimentos de reforma constitucional não incorporam, logicamente, mecanismos formais através dos quais a União Européia ou as Comunidades Autônomas possam decidir, por si mesmas, uma reforma constitucional. Certamente, as Comunidades Autônomas têm a possibilidade de apresentar propostas de reforma ${ }^{17}$. A União Européia, no entanto, não pode sequer promover a reforma constitucional. Por outra parte, o Tribunal Constitucional estabaleceu claramente que não são aceitáveis as modificações tácitas da Constituição justificadas por exigências derivadas do proceso de integração européia ${ }^{18}$. Com isso se resolve a questão no âmbito adequado, já que o pronunciamento do Tribunal Constitucional, a meu juízo irreprochável, não evita que estas reformas possam se produzir pois, justamente pela natureza destas modificações, seu controle é difícil (o que não deixa de ser, por certo, um argumento a mais a favor da doutrina assentada pelo Tribunal Constitucional) ${ }^{19}$.

Em todo caso, apesar das limitações formais que podem ser constatadas para a União Européia e para as Comunidades Autônomas, no âmbito da reforma, faz parte

\footnotetext{
${ }^{17}$ De acordo com a remissão que o artigo 166 CE faz ao 87.1 e 2 CE: “A iniciativa da reforma constitucional será exercida nos termos previstos nos parágrafos 1 e 2 do Artigo 87”. E no 87: “1. A iniciativa legislativa corresponde ao Governo, ao Congresso y ao Senado, de acordo com a Constituição e os Regimentos das Câmaras.

2. As Assembléias das Comunidades Autônomas poderão solicitar do Governo a adoção de um projecto de lei ou remeter à Mesa do Congresso uma proposta de lei, delegando ante dita Câmara um máximo de três membros da Assembléia encarregados de sua defesa”.

${ }^{18}$ Desta forma decidiu o Tribunal Constitucional na Declaração de 1 de Julho de 1992, emanada a requerimento do Governo da Nação e em cumprimento do previsto no art. 95.1 CE, referente ao Tratado de Maastricht. O Tribunal Constitucional declarou que era necessária a reforma da Constituição, e em concreto do art. 13.2, seguindo o procedimento ordinário de reforma do art. 167 CE. Para o Tribunal Constitucional “existe uma contradição irredutível pela via de interpretação, entre o art. 8 B, parágrafo 1, do Tratado da Comunidade Econômica Européia, segundo ficaria o mesmo redatado pelo Tratado da União Européia, por um lado, e o art. 13.2 de nossa Constituição por outro; contradição que afeta a parte daquele preceito que reconheceria o direito de sufrágio passivo nas eleições municipais a um conjunto genérico de pessoas (os nacionais de outros países-membros da Comunidade) que não têm a condição de espanhóis”. O Tribunal Constitucional entendeu que "tampouco o artigo 93 da Constituição se prestaria a ser empregado como instrumento para contrariar ou retificar mandatos ou proibições contidas na Norma fundamental, pois, nem tal preceito é via legítima para a reforma constitucional implícita ou tácita, nem poderia ser chamada atribuição do exercício de competências, em coerência com esse raciocínio, uma tal contradição, atravás do Tratado, dos imperativos constitucionais”. Cfr. igualmente, DTC 1/2004, de 13 de Dezembro de 2004, FJ 4.

${ }^{19}$ Cfr. sobre as questões suscitadas acerca deste tema, F. Rubio LLorente, "La Constitución española y el Tratado de Maastricht”, 1992, agora na recompilação do mesmo autor, La forma del Poder (estudios sobre la Constitución), CEC, Madrid, 1993; J.F. López Aguilar, "Maastricht y la problemática de la reforma de la Constitución”, REP, n. 77, 1992; J.L. Prada Fernández de Sanmamed, "Examen de urgencia de la alternativa entre reforma y mutación constitucional ante la integración europea”, em AAVV: Estudios de Derecho Público en Homenaje a Juan José Ruiz-Rico, Editorial Tecnos, Vol. I, Madrid, 1997.
} 
quase inevitável da natureza das coisas que a distribuição territorial do poder político incida no âmbito constitucional como o faz no infra-constitucional. Embora, como vimos, a Constituição não estabeleça, por si mesma, a pluralidade ordenamental ${ }^{20}$, esta pluralidade abre passo através das remissões, nela realizadas, aos Estatutos de Autonomia das Comunidades Autónomas ${ }^{21}$ e à integração na Europa ${ }^{22}$. O processo se desenvolve a partir das previsões constitucionais, porém de maneira externa à própria Constituição. No entanto, é a própria Constituição que realiza estas remissões e que possibilita a formação de estruturas "constitucionais" no âmbito interno e a incorporação a estruturas desta natureza no âmbito europeu.

A interação constitucional entre estes âmbitos é, portanto, inevitável e daí que a doutrina tenha insistido nos efeitos que esta interação provocou e está provocando. Poderíamos dizer que a União Européia já está exercitando poder constituinte sobre os Estados-membros ${ }^{23}$, se bem que não se trata de um poder constituinte originário senão derivado ${ }^{24}$. Este exercício de poder de reforma é congruente com a especial fase de transição na qual se encontra o processo de integração. Neste momento, é possível afirmar que os Estados-membros já perderam em grande parte a condição de ordenamentos originários enquanto a União Européia ainda não adquiriu plenamente esta condição (à qual poderá chegar uma vez que exista uma autêntica Constituição européia) ${ }^{25}$.

A interação entre a ordem constitucional incipiente da União Européia e a consolidada dos Estados-membros constitui uma realidade cada vez mais tangível ${ }^{26}$.

${ }^{20}$ Cfr. a respeito, F. Balaguer "Das System der Rechtsquellen in der spanischen Verfassungsrechtsordnung” Jahrbuch des öffentlichen Rechts der Gegenwart, Mohr Siebeck, Tübingen, Bd. 49, 2001, pp. 414, 426. Por outra parte, tampouco tem que fazê-lo já que a pluralidade de ordenamentos e de fontes possibilita remissões posteriores pois, como indica P. Häberle, não há um numerus clausus de fontes do Direito no Estado constitucional. Cfr. "Rechtsquellenprobleme im Spiegel neuerer Verfassungen- ein Textstunfenvergleich", ARSP, Beiheft 62, 1995, pp. 138-9.

${ }^{21}$ Assim, por exemplo, no artigo 147.1: "Dentro dos termos da presente Constituição, os Estatutos serão a norma institucional básica de cada Comunidade Autônoma e o Estado os reconhecerá e amparará como parte integrante de seu ordenamento jurídico”.

${ }^{22}$ Artículo 93: "Mediante lei orgânica poder-se-á autorizar a celebração de tratados através dos quais se atribua a uma organização ou instituição internacional o exercicio de competências derivadas da Constituição. Corresponde às Casas do Poder Legislativo ou ao Governo, segundo os casos, a garantia do cumprimento destes tratados e das resoluções emanadas dos organismos internacionais ou supranacionais titulares da cessão”.

${ }^{23}$ A este respeito P. Häberle se refere à "europeização" da teoria do poder constituinte e do poder de reforma, assim como da Europa como poder constituinte mediato ou indireto, embora não por referência somente à União Européia (também ao Conselho de Europa, por exemplo). Cfr. P. Häberle, "Europa -eine Verfassungsgemeinschaft?”, na recompilação do mesmo autor Europäische Verfassungslehre in Einzelstudien, Nomos, Baden-Baden, 1999, pp. 94-5. Cfr. num sentido mais amplo, a abordagem deste autor sobre o Estado constitucional cooperativo: P. Häberle, "Der kooperative Verfassungsstaat, 1978, ahora en Verfassung als öffentlicher Prozeß. Materialien zu einer Verfassungstheorie der offenen Gesellschaft, Duncker \& Humblot, Berlin, 1996. Cfr. igualmente W. Von Simson, Die Souveränität im rechtlichen Verständnis der Gegenwart, Duncker \& Humblot, Berlin, 1965.

${ }^{24}$ Cfr. F. Balaguer Callejón, "La constitucionalización de la Unión Europea y la articulación de los ordenamientos europeo y estatal”, em Miguel Angel García Herrera (dir.): El constitucionalismo en la crisis del Estado social, Universidad del País Vasco, Bilbao, 1997, pp. 595-6.

${ }^{25}$ Ibídem, pp. 596-7.

${ }^{26}$ Cfr. P. Häberle “Gemeineuropäisches Verfassungsrecht” em EuGRZ, 1991. Existe versão espanhola de Emilio Mikunda, “Derecho constitucional común europeo”, na Revista de Estudios Políticos, nº 79, Madrid, 1993. Igualmente, de Peter Häberle, "Die europäische Verfassungsstaatlichkeit”, em Kritische Vierteljahresschrift 
No nosso caso, não gera somente possíveis relações de conflito com incidência no âmbito da reforma constitucional, como também claras relações de confluência, através da integração do Direito europeu no bloco de constitucionalidade ${ }^{27}$. Por mais que esta integração seja expressamente negada pelo Tribunal Constitucional, nas suas próprias decisões podem ser vistas manifestações de uma orientação contrária aos pronunciamentos doutrinários expressos ${ }^{28}$.

Uma reflexão similar acerca da interação especificamente constitucional produzida, em relação à ordem estatutária e constitucional, é possível. Prova disto foram, por exemplo, os suscessivos Pactos Autonômicos que contribuíram para conformar o Estado autonômico. Porém, não somente estes Pactos, porque exatamente neste âmbito foi possível constatar uma permanente capacidade de “inovação" ou, ao menos de interpretação muito extensiva do contexto constitucional, que permitiria falar também de mutações num sentido similar ao que vimos anteriormente em relação à União Européia $^{29}$. Além desta vertente ativa da interação constitucional (exercício do poder de reforma sobre a Constituição, provocando mutações constitucionais), há uma constante reafirmação doutrinária da vertente passiva (impossibilidade do exercício do poder de reforma por parte das instâncias gerais). Deste modo, considera-se que o Estado autonômico está garantido frente à reforma constitucional em virtude de diversos expedientes. Haveria assim uma limitação implícita à reforma constitucional que poderia ser determinada a partir de certas previsões do texto constitucional ${ }^{30}$. A estas razões me permitiria acrescer as que se derivam da própria consolidação do Estado autonômico.

Todavia, a tensão constitucional gerada pelas Comunidades Autônomas não se manifiesta somente através da atividade direta dos agentes políticos, mas também por meio da jurisdição constitucional. É o Tribunal Constitucional que, ao atuar como árbitro entre a interpretação constitucional do Estado e a das Comunidades Autônomas, define e redefine os perfis do Estado autonômico. Para tanto, não se pode ignorar o

für Gesetzgebung und Rechtswissenschaft, Heft 3/1995. Existe versão espanhola de Francisco Balaguer Callejón: "El Estado constitucional Europeo”, em Cuestiones Constitucionales. Revista Mexicana de Derecho Constitucional. $\mathrm{n}^{\circ}$ 2, Mexico, Enero-Junio de 2000. Por último, do mesmo autor, "Europa als werdende Verfassungsgemeinschaft", conferência pronunciada em Granada em março de 2000. Existe versão espanhola de Francisco Balaguer Callejón, "Europa como comunidad constitucional en desarrollo", Revista de Derecho Constitucional Europeo, ${ }^{\circ}$ 1, Enero-Junio de 2004, pp. 11-24. Versão electrónica en http://www.ugr.es/ redce.

${ }^{27}$ Cfr. sobre o bloco de constitucionalidade, F. Rubio LLorente, "El bloque de constitucionalidad" REDC, $n^{\circ} 27,1989$.

${ }^{28}$ Cfr. F. Balaguer Callejón, "La constitucionalización de la Unión Europea y la articulación de los ordenamientos europeo y estatal”, cit., pp. 602 y ss., y “Das System der Rechtsquellen in der spanischen Verfassungsrechtsordnung”, cit., pp. 435 y ss.

${ }^{29}$ Cfr. por todos, J. Tomas Villarroya, "Proceso autonómico y observancia de la Constitución”, $R E D C \mathrm{n}^{\circ} 15$, 1985, pp. 25 ss.

${ }^{30}$ Cfr. a respeito J. Ruipérez, La protección constitucional de la autonomía, Tecnos, Madrid, 1994 e do mesmo autor: Constitución y autodeterminación, Tecnos, Madrid, 1995, assim como "Principio democrático y federalismo. El poder constituyente como único soberano posible en el Estado políticamente descentralizado", Anuario da Facultad de Dereito da Universidade da Coruña, n. 3, 1999. Cfr. igualmente sobre este tema J.J. Solozábal Echevarría, "El problema de la soberanía en el Estado autonómico”, Fundamentos, n. 1, Oviedo, 1998. 
caráter dinâmico adquirido por esta definição, porquanto não pode ser alheia ao caráter das pretensões esgrimidas pelas partes. ${ }^{31}$ A ausência de reivindicação autonômica nos situaria, sem dúvida, ante um Estado autonômico mais centralizado do que o que temos hoje. Por outro lado, a permanente resignação do Estado frente às pretensões autonômicas poderia ter produzido uma maior descentralização.

Algumas conclusões já podem ser extraídas das considerações anteriores:

1. Para começar, caberia destacar que as tensões básicas no sistema constitucional espanhol gradativamente se concentraram na distribuição territorial do poder. Isto não implica que haja ausência de tensões noutros espaços, mas antes que a incidência constitucional da conflitividade destes outros espaços tenderam a se estabilizar ou inclusive a diminuir enquanto a produzida pela distribuição territorial aumenta. Este deslocamento encontra sua explicação no fato de que justamente na distribuição territorial se situam os conflitos políticos (conflitos de poder) com mais incidência constitucional. Já não se trata da inexistência de tensões no interior do sistema político estatal e na definição das instituições constitucionais que o regulam, senão da geração, por parte destas tensões, de menor conflitividade constitucional, que, quando surge, geralmente é pacificada de maneira estável através das decisões do Tribunal Constitucional. Por outro lado, os conflitos relacionados com a distribuição territorial do poder incidem, em regra, diretamente no nível constitucional e são mais dinâmicos, ficando abertos, em muitas ocasiões, a uma eventual reconsideração por parte da jurisdição constitucional.

2. Uma segunda conclusão, de caráter metodológico, deve ser adiantada. Trata-se da incidência da existência do nível europeu e do autonômico sobre a análise do direito constitucional. Estes níveis já não podem ser ignorados no estudo do direito constitucional. Tanto o processo de integração européia como a configuração do Estado autonômico nos obrigam a valorar as instituições constitucionais levando em conta estas variáveis com uma nova abordagem metodológica. A interação entre o nível europeu, o estatal e o autonômico está destinada a ser cada vez mais intensa e, por isto, terá que ser levada em conta cada vez mais na análise singularizada destes níveis.

Dentro desta vertente metodológica caberia integrar também a incidência do fator tempo sobre as questões constitucionais. É difícil utilizar regras padronizadas de medida do tempo no direito constitucional. As lentas etapas pelas quais passaram determinadas instituições em alguns sistemas constitucionais, e que serviram para seu desenvolvimento e consolidação, não têm, necessariamente, que ser superadas na totalidade por outros, que podem usar esta experiência prévia para avançar ainda mais. Justifica-se, aqui, a aplicação do paradigma do desenvolvimento gradual dos textos

\footnotetext{
${ }^{31}$ Um exemplo de até que ponto podem incidir as pretensões dos agentes políticos no plano constitucional temos na jurisprudência relativa à relação entre Poder Judicial e CCAA. De fato, apesar da contundência do princípio de interpretação constitucional dos Estatutos de Autonomia, proclamado pelo Tribunal Constitucional, tivemos exemplos do que poderíamos qualificar como uma "interpretação estatutária da Constituição", na qual se deu maior relevância às prescrições estatutárias que à literalidade do texto constitucional Cfr. F. Balaguer Callejón, "Poder Judicial y Comunidades Autónomas”, Revista de Derecho Político, n. 47, Madrid, 2000, p. 58.
} 
constitucionales de P. Häberle ${ }^{32}$. Ao mesmo tempo, o nível de aceleração dos sistemas constitucionais pode ser muito diverso, entre si, e isto faz com que reformas materiais (mutações, caso se prefira) possam se justificar em períodos de tempo relativamente curtos. Este tipo de situação ocorreu com freqüência no processo de desenvolviemnto do Estado autonômico, e também para as “constituições” das CCAA, para os Estatutos de autonomia, nos quais o nível extra-estatutário de desenvolvimento institucional foi muito amplo, as vezes em decorrência da falta de previsão estatutária, as vezes provocando mutações no Estatuto. Em todo caso, é necessário levar em conta o caráter dinâmico da interação entre as ordens européia, estatal e autonômica, que se incrementa na medida em que, nem no europeu se culminou ainda o processo de plena constitucionalização, ${ }^{33}$ nem no autonômico se culminaram as reformas constitucionais exigidas pela consolidação do Estado autonômico ${ }^{34}$.

\section{A TENDÊNCIA À FRAGMENTAÇÃO DO PODER CONSTITUINTE}

A tendência à fragmentação do poder constituinte é, por assim dizer, a outra cara da moeda em relação à progressiva limitação jurídica do poder constituinte originário. Com efeito, se o processo de integração européia impede de já se falar de um poder constituinte originário nos Estados-membros, ao mesmo tempo não permite que falemos ainda de um poder constituinte originário europeu. Estamos pois, em presença de um poder constituinte fragmentado, de um poder constituinte limitado similar, ao poder de reforma.

Isto é aplicável à ordem constitucional espanhola. Já não cabe duvidar da existência de limites materiais à reforma, derivados, de antemão, da integração de nosso país à União Européia. À medida em que este processo adquire caracteríticas de irreversibilidade, pode-se falar da impossibilidade de intervenção do poder constituinte originário no nosso ordenamento constitucional e da transformação, para estes fins, do poder constituinte em poder de reforma. Esta é a principal conseqüência da fragmentação do poder constituinte. Por outro lado, à medida que o processo de integração européia avance, os limites materiais serão mais estritos e, portanto, o poder de reforma terá uma menor margem de manobra. Se estas afirmações são corretas, poderíamos falar de mutações que afetam os próprios procedimentos de reforma da Constituição, ao invés de mutaciones constitucionais sobre o conteúdo material da Constituição. Estas nos definem a vertente ativa do processo: o exercício do poder de

\footnotetext{
${ }^{32}$ Cfr. Peter Häberle, “Textstufen als Entwicklungswege des Verfassungsstates”, 1989, agora na recompilação do mesmo autor Rechtsvergleichung im Kraftfeld des Verfassungsstaates. Methoden und Inhalte, Kleinstaaten und Entwicklungsländer, Duncker \& Humblot, Berlín, 1992. Cfr. alguns exemplos em "Die Grundrechte im Spiegel der Judikatur des BverfGE. Darstellung und Kritik”, versão espanhola de Francisco Balaguer Callejón, "Los derechos fundamentales en el espejo de la jurisprudencia del Tribunal Constitucional Federal Alemán. Exposición y crítica”, publicado na Revista de la Facultad de Derecho de la Universidad de Granada, $\mathrm{n}^{\circ}$ 2, Granada, 1999, pp. 14, 22, 28-9.

${ }^{33}$ Não cabe dúvida de que estamos e estaremos durante muitos anos, como indica o professor Rubio LLorente, numa "situação constituinte” no âmbito europeu. Cfr. F. Rubio LLorente, "El constitucionalismo de los Estados integrados de Europa”. Estudio Preliminar a F. Rubio LLorente/M. Daranas Peláez, Constituciones de los Estados de la Unión Europea, Ariel, Barcelona, 1997, p. XXVI.

${ }^{34}$ Cfr. a respeito, F. Balaguer Callejón, "La constitucionalización del Estado autonómico”, Anuario de Derecho constitucional y Parlamentario, $\mathrm{n}^{\circ}$ 9, Murcia, 1997.
} 
reforma pela União Européia. Aquelas, sua vertente passiva: as limitações que a integração na União Européia gera no exercício do poder de reforma estabelecido na Constituição.

Algo similar poderia ser dito do processo de descentralização que conduziu ao Estado autonômico. Além da potencial incidência da existência das CCAA sobre o desenvolvimento do nível constitucional do ordenamento na sua vertente ativa (provocando mutações constitucionais sobre o conteúdo material da Constituição), cabe valorar também até que ponto o desenvolvimento do Estado autonômico não está incidindo sobre os limites à reforma (vertente passiva da interação constitucional à qual aludimos antes). Já não se trata de limitações derivadas de princípios constitucionais incorporados ao próprio texto da Constituição, como podem ser o direito à autonomia ou o princípio democrático. Caberia falar, mais apropriadamente, de limitações derivadas da consolidação do Estado autonômico e da criação de centros de poder político que exercitam competências e que interagem com as instituições gerais do Estado também no nível constitucional.

Tanto no plano europeu como no autonômico esta abordagem pode soar estranha caso se leve em conta que não seria necessário produzir qualquer reforma formal da Constitución para que o Estado se desvinculasse do processo de integração européia ${ }^{35}$ ou para suprimir a autonomia política das CCAA existentes. Em ambos os casos o nível legislativo seria suficiente, afrontando as responsabilidades internacionais correspondentes em relação à União Européia e sempre que houvesse conformidade nas CCAA (mediante a reforma dos Estatutos de Autonomia) em relação ao Estado autonômico. No entanto, a questão é se a dinâmica constitucional gerada no nível europeu e no autonômico não acabou por superar as prescrições constitucionais neste aspecto.

A progressiva fragmentação do poder constituinte gera alguns questionamentos para o Direito constitucional. Se esta fragmentação desse lugar a uma plena equiparação entre poder de reforma e poder constituinte (ao desaparecer o caráter juridicamente ilimitado deste último) seriam questionadas as funções desenvolvidas por este e pela própria diferenciação entre poder constituinte e poder de reforma. No entanto, cabe dizer que tal equiparação não se produz mais que no aspecto parcial relativo aos limites que a fragmentação do poder constituinte introduz no seu exercício. No mais, permanece de pé a diferenciação sustancial entre poder de reforma e poder constituinte.

Cabe levar em conta que a unidade da Constituição e do ordenamento jurídico é um reflexo daquela do poder constituinte. Esta unidade poderia ser comprometida se não existisse mais, em nenhum âmbito do ordenamento, o exercício de um poder constituinte unitário. Por outro lado, e em conexão com o anterior, o poder constituinte dá lugar a uma ordenação que pretende ser sistemática, porquanto não atua de maneira parcial, mas instaura uma ordem constitucional inteira. Isto não ocorre com o poder de reforma. O poder de reforma pode dar lugar a modificações essenciais da ordem

${ }^{35}$ Cabe levar em conta, a este respeito, o direito de retirada voluntária dos Estados-membros, que o Tratado Constitucional establecia no seu art. I-60 e o Projeto de Tratado de Reforma contempla como art. 35 TUE. 
constitucional. Entretanto, serão sempre modificações parciais (pois, noutro caso, haverá um autêntico exercício do poder constituinte e uma nova Constituição).

Tudo isto não impede de levar em conta que o poder constituinte e o poder de reforma participam de uma mesma natureza. O resultado do exercício de ambos os poderes é uma ordenação constitucional. A partir desta perspectiva, a fronteira que separa o poder constituinte originário do derivado sempre será inestável. Do ponto de vista do resultado final, ambos contribuem com normas constitucionais para o ordenamento.

Contudo, apesar de se chegar por vias diferentes ao mesmo resultado, na realidade, reforma constitucional e poder constituinte respondem a uma distinta razão de ser e, portanto, não podem se identificar. O momento de instauração de uma Constituição nunca poderá ser equiparado totalmente ao da reforma, inclusive se o poder constituinte está submetido a limitações jurídicas prévias. Não só por que a instauração de uma nova ordem constitucional sempre traz consigo uma nota de plenitude da qual carece a reforma, como também por que aos limites jurídicos que possam condicionar o poder constituinte, este pode acrescer os que estime convenientes em relação ao poder de reforma. Fica claro, portanto, que a progressiva fragmentação do poder constituinte não subtrai utilidade à diferenciação teórica entre poder constituinte e poder de reforma. A fragmentação implica unicamente que a característica distintiva do poder constituinte originário já não pode ser a de sua configuração como um poder estritamente político e carente de limites materiais. Não obstante, além de seus novos limites, o poder constituinte intervêm com plena capacidade de decisão política configurando uma nova ordem constitucional.

\section{NECESSIDADES CONSTITUCIONAIS DA SOCIEDADE E REFORMA CONSTITUCIONAL}

A reforma constitucional não é só uma técnica a serviço da supremacia constitucional, mas também um mecanismo de adaptação da Constituição às novas exigências sociais e/ou de correção das deficiências dos preceitos constitucionais. Partindo desta perspectiva, a estabilidade constitucional se baseia no equilíbrio entre as exigências derivadas da garantia de normatividade constitucional e a obrigada resposta às necessidades constitucionais da sociedade. A conexão entre ambas as facetas é inevitável: a excessiva rigidez pode prejudicar a posição da Constituição no ordenamento, obrigando os agentes políticos e jurídicos a buscar vias alternativas para fazer frente a estas necessidades constitucionais. Ao mesmo tempo, uma excesiva flexibilidade pode conduzir à desnaturalização do sentido normativo da Constituição enquanto expressão do consenso fundamental da sociedade, caso permita a modificação em atendimento à vontade da maioria.

É preciso enfatizar que a reforma constitucional pode passar a um segundo plano caso a jurisdição constitucional possibilite a adaptação dos preceitos constitucionais às novas exigências sociais ${ }^{36}$. A jurisdição constitucional é, sem dúvida, um fator

${ }^{36}$ Como indica J. Pérez Royo, a partir do momento em que a instituição da reforma adquire na Europa o nível de uma autêntica garantia jurídica (a partir da segunda pós-guerra) deixa de ser também o instrumento fundamental para adequar o texto constitucional à mutável realidade social e política, convertendo-se tão 
essencial no processo de renovação do ordenamento. Junto a ela, os demais agentes jurídicos e os agentes políticos agem sobre o texto constitucional contribuindo ao desenvolvimento constitucional (recordemos aqui a tese de P. Häberle sobre a sociedade aberta dos intérpretes constitucionais ${ }^{37}$ ). Partindo desta perspectiva não se pode ignorar que as necessidades constitucionais da sociedade não são cobertas pelo binômio Constituição-reforma constitucional. Na atualidade, como tivemos ocasião de ver, são muitos os agentes que intervêm sobre a Constituição espanhola além do poder constituinte derivado do nível estatal. Junto à jurisdição constitucional e os agentes jurídicos e políticos cabe levar em conta também a incidência do pluralismo ordenamental sobre a Constituição: as Comunidades Autônomas e a União Européia interagem com a ordem constitucional gerando novos desenvolvimentos. Do mesmo modo que a estrutura estatal influi na européia e na autonômica, estas últimas o fazem sobre aquela. Em última instância, esta interação recíproca tenta fazer frente às necesidades constitucionais da sociedade, nos seus diversos níveis.

No que se refere à jurisdição constitucional, esta deixa num segundo plano os procedimentos não formalizados de produção de direito no âmbito constitucional ${ }^{38}$. Os conflitos jurídicos se transferem para o Tribunal Constitucional e é este órgão que resolve tais conflitos de acordo com critérios que consolidam uma determinada configuração do ordenamento: a que a partir do texto constitucional está contida na doutrina constitucional. Esta doutrina outorga ao sistema constitucional a flexibilidade oferecida, antigamente, pelos procedimentos não formalizados de produção, porquanto através da jurisprudência constitucional esta configuração também se modifica.

A generalidade e ambigüidade dos preceitos constitucionais são também elementos que outorgam uma ampla flexibilidade ao sistema, tornando desnecessário o recurso a outros instrumentos como o costume ou as convenções. Pode-se dizer o mesmo acerca do caráter aberto do texto constitucional no que se refere à remissão à leis, sobretudo orgânicas, que permitem à maioria no poder configurar de maneira muito distinta o ordenamento constitucional a partir do texto da Constituição. O mesmo ocorre com a Constituição territorial ${ }^{39}$, porquanto a Constituição continha somente

só em garantia excepcional que se justapõe à garantia normativa, a da Justicia constitucional. É, com efeito, a Justiça constitucional que realiza esse labor por meio da interpretação da Constituição. A reforma da Constituição permanece assim como um recurso de emergência à qual só se acude quando não é possível solucionar o problema de que se trata mediante a interpretação constitucional (o que não quer dizer, no entanto, que não seja um recurso utilizado com freqüência na prática). Cfr. J. Pérez Royo, ”La reforma de la Constitución”, $R D P$, n. 22, 1986, pp. 7 ss.

${ }^{37}$ P. Häberle, "Die offene Gesellschaft der Verfassungsinterpreten” (1975) y "Verfassungsinterpretation als öffentlicher Prozeß -ein Pluralismuskonzept” (1978), agora na recompilação do mesmo autor, Die Verfassung des Pluralismus, Athenäum, Königstein/Ts., 1980, pp. 79 y 45, respectivamente.

${ }^{38}$ Sobre estes últimos, cfr. P. de Vega, La reforma constitucional y la problemática del poder constituyente, cit., pp. 179 ss., J.A. Santamaría Pastor, Fundamentos de Derecho Administrativo Vol. I, Editorial Centro de Estudios Ramón Areces, Madrid 1988, pp. 499 ss.; P. Lucas Verdu, Curso de Derecho político, Vol. IV, Tecnos, Madrid, 1984, pp. 158 ss.; P. J. Gonzalez Trevijano, La costumbre en Derecho constitucional, Congreso de los Diputados, Madrid, 1989; A. Elvira Perales, "Las convenciones constitucionales", $R E P$, n. 53, 1986.

${ }^{39}$ Na expressão de P. Cruz Villalón, “La Constitución territorial del Estado”, 1990, agora na recompilação do mesmo autor La curiosidad del jurista persa y otros estudios sobre la Constitución, CEPC, Madrid, 1999. 
uma estrutura aberta a uma pluralidade de opções que tiveram que ser adotadas pelos agentes jurídicos ${ }^{40}$. Quanto mais liberdade têm os agentes jurídicos para decidir através dos procedimentos ordinários de produção jurídica em conformidade com o contexto oferecido pela Constituição, menos necessidade há de recorrer a procedimentos não formalizados.

Por outra parte, os costumes constitucionais, da mesma forma que a reforma constitucional ou a jurisprudência do TC são instrumentos para afrontar as necessidades constitucionais da sociedade. Historicamente, nas relações entre os poderes do Estado, estas necessidades se situaram no Estado centralizado. Na atualidade, no entanto, o âmbito no qual as necessidades constitucionais se evidenciam com maior intensidade é o das relações entre ordenamentos: no nível europeu e no autonômico. Na medida em que nestes níveis as necessidades constitucionais não sejam afrontadas mediante a reforma constitucional, a jurisprudência ou os instrumentos que dão flexibilidade ao sistema, existe a possibilidade de que apareça o direito consuetudinário como alternativa.

Certamente, não se pode dizer que a única reforma produzida até agora, exigida pela ratificação do Tratado da União Européia ${ }^{41}$, e que só afetou um preceito constitucional $^{42}$, seja prova da capacidade de adaptação formal, via reforma, da Constituição às necessidades constitucionais da sociedade. No sistema constitucional espanhol, a reforma sempre foi evitada: em tempos de instabilidade política as reformas não são promovidas devido a esta instabilidade. Em tempos de estabilidade não são promovidas para não provocar instabilidade. Todas as soluções tentadas para fazer frente aos problemas de ordenação constitucional parecem ter como inspiração essencial a vontade de evitar a reforma constitucional para não se abordar novamente o pacto constituinte (especialmente no que se refere à estrutura territorial do Estado). No entanto, por esta via, a normatividade da Constituição acaba se debilitando e o pacto constituinte passa a ser abordado de maneira permanente no processo político. Não parece que esta tendência vá se modificar no futuro imediato. O déficit constitucional terá que se resolver, enquanto for possível, mediante a intervenção do Tribunal Constitucional ${ }^{43}$ ou através de pactos políticos.

No que se refere ao processo de integração na Europa, também se evidencia o déficit constitucional no âmbito interno; por exemplo, na articulação de políticas normativas que facilitem as relações entre ordenamentos. A reforma do Senado, estritamente necessária se levamos em conta o grau de federalização do Estado autonômico, já é ineludível em atenção ao proceso de integração na Europa. Como não se afronta esta reforma, coube buscar mecanismos alternativos para possibilitar a integração das políticas estatais e autonômicas entre si e com as européias.

\footnotetext{
${ }^{40}$ Questão distinta, conforme indicamos, é a da reversibilidade destas opções todas as vezes que o desenvolvimento das mesmas tenha suposto uma autêntica reestruturação do Estado que afete necessariamente a ordem constitucional.

${ }^{41}$ Cfr. Declaração do Tribunal Constitucional de 1 de Julho de 1992, já referida.

42 Acrescendo, como se sabe, os termos “e passivo" em relação ao direito de sufrágio dos estrangeiros nas eleições municipais no artigo 13.2 CE.

${ }^{43}$ Razão pela qual, conforme indica Carlos de Cabo, exige-se em alguns âmbitos não mais uma doutrina constitucional e sim uma “doutrina constituinte”, cfr. Carlos de Cabo Martín, La reforma constitucional en la perspectiva de las fuentes del Derecho, Ed. Trotta, Madrid, 2003, pp. 77-78.
} 
Porém estes mecanismos podem conduzir a uma desvalorização do Parlamento como órgão de representação e de expressão do pluralismo.

Vimos até agora a interação constitucional produzida entre os âmbitos europeu, estatal e autonômico, tanto na sua vertente ativa (exercício do poder de reforma derivado da pluralidade ordenamental que dá lugar a mutações sobre o conteúdo material da Constituição) como passiva (limites ao poder de reforma estabelecido na Constituição derivados desta pluralidade ordenamental). É preciso destacar que a interação constitucional não é atribuível só aos agentes constitucionais europeus ou autonômicos, pois esta interação se produz no triplo âmbito enunciado (europeu, estatal e autonômico) e entre todos os agentes constitucionais. Por outro lado, tampouco se pode deixar de destacar que a capacidade de resolver as necessidades constitucionais mediante modificações materiais não é ilimitada. Justamente da interacción constitucional deriva-se a necessidade de afrontar os novos cenários que se desenvolveram a partir da Constituição mediante reformas do texto constitucional em muitos aspectos, se bem que, conforme veremos, as propostas feitas até agora não deram bom resultado.

\section{A REFORMA CONSTITUCIONAL NO NÍVEL ESTATAL: PROPOSTAS DE REFORMA E DIFICULDADES PARA LEVÁ-LAS À CABO}

Na Constituição espanhola encontram-se previstos dois procedimentos de reforma constitucional, o procedimento ordinário (art. $167 \mathrm{CE}$ ) e o procedimento agravado (art. $168 \mathrm{CE}$ ). A iniciativa do procedimento está prevista no art. $166^{44}$, que remete aos parágrafos 1 e 2 do art. $87^{45}$.

O procedimento ordinário de reforma previsto no art. 167 CE deve ser valorado positivamente, porquanto equilibra adequadamente a tensão entre normatividade e flexibilidade experimentada no âmbito do instituto da reforma ${ }^{46}$. O procedimento agravado, no entanto, não pode ser merecedor de uma valoração positiva, porquanto estabelece condições excesivamente rígidas que convertem a reforma numa operação muito difícil de realizar na prática. Difícil, porém não impossível, já que a Constituição espanhola não estabelece limites materiais à reforma ${ }^{47}$.

\footnotetext{
44 “A iniciativa de reforma constitucional será exercida nos termos previstos nos parágrafos 1 e 2 do art. 87”.

${ }^{45}$ Com base nestes preceitos, já referidos: “1. A iniciativa legislativa corresponde ao Governo, ao Congresso e ao Senado, de acordo com a Constituição e os Regimentos das Câmaras. 2. As Assembléias das Comunidades Autônomas poderão solicitar do Governo a adoção de um projecto de lei ou remeter à Mesa do Congresso uma proposta de lei, delegando ante dita Câmara um máximo de três membros da Assembléia encarregados de sua defesa".

${ }^{46}$ De acordo com o disposto no art. $167 \mathrm{CE}$ : “1. Os projetos de reforma constitucional deverão ser aprovados por uma maioria de três quintos em cada uma das Câmaras. Se não houver acordo entre ambas, tentar-se-á obtê-lo mediante a criação de uma Comissão de composição paritária de Deputados e Senadores, que apresentará um texto que será votado pelo Congresso e pelo Senado. 2. Caso não seja lograda a aprovação mediante o procedimento do parágrafo anterior, e sempre que o texto tenha obtido o voto favorável da maioria absoluta do Senado, o Congresso por maioria de dois terços poderá aprovar a reforma. 3. Aprovada a reforma por ambas as Casas do Poder Legislativo, será submetida à referendo para sua ratificação quando assim solicitem, dentro dos quinze dias seguintes à sua aprovação, a décima parte dos membros de qualquer uma das Câmaras”.

${ }^{47} \mathrm{O}$ único limite é temporal. O artigo 169 dispõe que "Não se poderá iniciar a reforma constitucional em tempo de guerra ou de vigência de qualquer dos estados previstos no artigo 116” (refere-se aos estados de emergência, exceção ou sítio).
} 
Como já tivemos ocasião de ver, a história da reforma constitucional na Espanha não contém muitas páginas: em praticamente trinta anos de vigência da Constituição, só um preceito foi reformado, através do procedimento ordinário, sem celebração de referendo. Trata-se do artigo 13.2 CE, que foi objeto da Reforma Constitucional de 27 de agosto de 1992 (BOE de 28 de agosto) através da qual se acrescia o inciso "e passivo", para tornar possível a ratificação do Tratado de Maastricht, em atendimento à prescrição do art. 95.1 $\mathrm{CE}^{48}$.

Naturalmente, a não elaboração e aprovação de reformas não é um indício da ausência de novas necessidades constitucionais. Ao contrário, num Estado que se integrou na Europa em 1986 e que experimentou uma amplíssima descentralização desde 1978, as reformas constitucionais já são absolutamente necessárias desde muitos anos atrás. No entanto, o temor de que o consenso tão dificilmente logrado no momento de aprovação da Constituição se rompesse na reforma, foi um obstáculo permanente à realização de reformas constitucionais.

O temor à ruptura do consenso tem sido especialmente intenso em relação às possíveis reivindicações dos setores nacionalistas periféricos, especialmente do País Vasco e da Catalunha. Por este motivo, conforme já indicamos, as reformas estacionaram e estas necessidades constitucionais foram afrontadas através de mecanismos e instituições que, embora sem contradizer os preceitos constitucionais, desenvolveram-se à margem da Constituição. É o caso, por exemplo, das Conferências Setoriais, que tentaram paliar as deficiências do Senado enquanto Câmara de coordenação das políticas estatais e autonômicas.

O partido atualmente na liderança do governo (2007) havia proposto em seu programa eleitoral de 2004 uma revisão limitada, para tentar obter o consenso mínimo que permitisse fazer as reformas mais urgentes. Definiram-se quatro âmbitos como objeto de modificação: o Senado, para configurá-lo como uma autêntica Câmara de representação territorial; a inserção de referências à União Européia; a incorporação da denominação oficial das Comunidades Autônomas ao texto constitucional e, finalmente, a modificação do parágrafo $1^{\circ}$ do art. 57, para eliminar a discriminação que assoma em detrimento da mulher na sucessão à Coroa. ${ }^{49}$

Para elaborar propostas concretas sobre cada um destes temas, o Conselho de Estado encomendou diversos estudos prévios com o objetivo de preparar o Parecer correspondente $^{50}$ que finalmente foi emitido em 16 de fevereiro de $2006^{51}$. No entanto,

\footnotetext{
${ }^{48}$ De acordo com sua nova redação, o parágrafo 2 do artigo 13 estabelece que "Somente os espanhóis serão titulares dos direitos reconhecidos no artigo 23, salvo o que, atendendo a critérios de reciprocidade, possa ser estabelecido por tratado ou lei sobre o direito de sufrágio ativo e passivo nas eleições municipais”.

${ }^{49}$ De acordo com o parágrafo $1^{\circ}$ do artigo 57: “A Coroa da Espanha é hereditária para os sucessores de SM Don Juan Carlos I de Borbón, legítimo herdeiro da dinastia histórica. A sucessão ao trono seguirá a ordem regular de primogenitura e representação, sendo preferida sempre a linha anterior às posteriores; na mesma linha, o grau mais próximo ao mais remoto; no mesmo grau, o homem à mulher, e no mesmo sexo, a pessoa de mais idade à de menos”.

${ }^{50}$ Cfr. Francisco Rubio Llorente, José Alvarez Junco (eds.) El informe del Consejo de Estado sobre la reforma constitucional. Texto del informe y debates académicos, anteriormente citado.

51 Cfr. http://www.consejo-estado.es/INFORME\%20SOBRE\%20MODIFICACIONES\%20DE\%20LA\%20 CONSTITUCION\%20 ESPAÑOLA.PDF
} 
todo este esforço foi inútil, até o presente momento, já que a oposição negou-se a considerar a possibilidade de reforma.

É necessário levar em conta, ademais, que a reforma teria que seguir o procedimento agravado do artigo 168, o que a dificulta extraordinariamente. Esta dificultade decorre da necessidade de proceder à dissolução das Casas do Poder Legislativo e convocar eleições para que as novas Casas aprovem a reforma. Num clima político tão tenso como o que se vive atualmente na Espanha um acordo que possibilite a ativação deste procedimento é impensável.

7. AS REFORMAS NO NÍVEL EUROPEU E NO NÍVEL AUTONÔMICO: MEDO AO DIREITO CONSTITUCIONAL ENQUANTO FATOR DE “ESTATALIZAÇÃO” DOS ORDENAMENTOS

A impossibilidade de efetuar as reformas no âmbito estatal esteve surpreendentemente unida a dificuldades nos níveis europeu e autonômico. O que há de surprendente é a causa comum compartilhada por ambos os níveis: o temor, por parte de alguns setores, de que a incorporação do Direito constitucional ao nível europeu e ao nível autonômico acabe sendo uma fórmula que permita criar um "Superestado" europeu ou entidades estatais em algumas das atuais Comunidades Autônomas.

\subsection{As reformas em nível autonômico}

Começando pelas reformas em nível autonômico, cabe dizer que constituem um exemplo claro dos problemas que podem surgir quando a revisão das normas fundamentais é adiada indefinidamente, abrindo espaço para que os problemas políticos se acrescentem e o nível reivindicativo aumente consideravelmente. A persistência na percepção de abandono e de falta de respeito à posição institucional dos órgãos autonômicos pode contribuir para uma radicalização que dificulte a posterior negociação política. Esta sensação é especialmente aplicável àqueles Estatutos que seguiram inicialmente a via do artigo 151 CE (Andaluzia, Catalunha, Galícia e País Vasco) e que ainda não haviam sido objeto de qualquer reforma (à diferença de outros que realizaram, a esta altura, sua terceira reforma).

É preciso diferenciar, não obstante, aquelas situações nas quais a reforma foi explicitamente proposta como uma confrontação com o Estado e a Constituição (Plano Ibarretxe) daquelas outras (o restante) nas quais, com maior ou menor acerto na definição das técnicas utilizadas para promovê-la, tentou-se manter uma congruência com a estrutura constitucional.

O Projeto de Reforma do Estatuto de Autonomia do País Vasco, formulado como "Proposta de reforma do estatuto político da comunidade de Euskadi”, foi rechaçado de maneira contundente pelo Congresso dos Deputados no dia $1^{\circ}$ de fevereiro de 2005, após uma longa polêmica política e doutrinária na qual a absoluta inadequação desta proposta à Constituição, em muitos dos seus aspectos, foi evidenciada.

Esta proposta de reforma estatutária era, na realidade, uma formulação que contradizia frontalmente a constituição e que, portanto, não poderia servir senão para ilustrar a via que não deveria ser seguida para abordar uma reforma estatutária. Para começar, o Plano Ibarretxe pretendia estabelecer a soberania do País Vasco, com o reconhecimento explícito de um direito de segregação do Estado e com a criação de 
uma nacionalidade Vasca (outorgando aos cidadãos vascos a condição de nacionais). Por outro lado, o Plano Ibarretxe também contradizia a Constituição de maneira frontal ao pretender impedir uma garantia mínima de ação estatal no País Vasco através da tentativa de rejeitar a aplicação dos artigos $155^{52}$ e $161.2^{53} \mathrm{CE}$ e de modificar a composição do Tribunal Constitucional (entre outras questões).

Tanto pela sua filosofia quanto pelo alcance de muitas de suas previsões, o Plano Ibarretxe era inaceitável e não poderia ser aprovado em seus termos pelas Casas do Poder Legislativo sem produzir uma importante ruptura com o sistema constitucional. Por outro lado, a negociação política foi descartada desde o princípio, dada a dificultade evidente em encontrar fórmulas de consenso que permitissem eliminar os graves problemas de constitucionalidade que o Plano apresentava.

Posteriormente à fracassada reforma do Estatuto do País Vasco, novas reformas, noutras Comunidades Autônomas, foram abordadas. As três primeiras foram aprovadas pelas Casas do Poder Legislativo ao longo de 2006. A primeira delas foi concluída pela Comunidade Valenciana (Lei Orgânica 1/2006, de 10 de abril, de Reforma da Lei Orgânica 5/1982, de $1^{\circ}$ de julho, do Estatuto de Autonomia da Comunidade Valenciana, BOE de 11 de abril de 2006). A segunda aprovada pelas Casas do Poder Legislativo foi a da Catalunha, submetida a referendo (Lei Orgânica 6/2006, de 19 de julho, de reforma do Estatuto de Autonomia da Catalunha, BOE de 20 de julho de 2006). A terceira foi a da Andaluzia, igualmente submetida a referendo, e publicada já em 2007, depois de aprovada em referendo (Lei Orgânica 2/2007, de 19 de março, de reforma do Estatuto de Autonomia da Andaluzia, BOE de 20 de março de 2007).

Até agora, em 2007, as Casas do Poder Legislativo aprovaram outras duas reformas. A quarta, apesar de ter sido publicada antes da andaluza por não precisar se submeter a referendo, foi a das Ilhas Baleares (Lei Orgânica 1/2007, de 28 de fevereiro, de reforma do Estatuto de Autonomia das Ilhas Baleares, BOE de $1^{\circ}$ de março de 2007). A última foi a de Aragão (Lei Orgânica 5/2007, de 20 de abril, de reforma do Estatuto de Autonomia de Aragão, BOE de 23 de abril). Na atualidade há três reformas pendentes de aprovação das Casas do Poder Legislativo (Canárias, Castela e Leão e Castela La Mancha).

De todas as reformas concluídas, pode-se dizer que não se produziu, em qualquer delas, uma confrontação radical com a Constituição (como ocorreu com o Plano Ibarretxe), apesar de que a constitucionalidade de diversos aspectos em todas elas

52 Artigo 155 CE: “1. Se uma Comunidade Autônoma não cumprir as obrigações que a Constituição ou outras leis lhe imponham, ou atuar de forma que atente gravemente contra o interesse geral da Espanha, o Governo, após requerimento ao Presidente da Comunidade Autônoma e, no caso de não ser atendido, com a aprovação por maioria absoluta do Senado, poderá adotar as medidas necessárias para obrigá-la ao cumprimento forçoso de ditas obrigações ou para a proteção do mencionado interesse geral. 2. Para a execução das medidas previstas no parágrafo anterior, o Governo poderá dar instruções a todas as autoridades das Comunidades Autônomas”.

${ }^{53}$ Artículo 161.2 CE: "O Governo poderá impugnar ante o Tribunal Constitucional as disposições e resoluções adotadas pelos órgãos das Comunidades Autônomas. A impugnação produzirá a suspensão da disposição ou resolução recorrida, porém o Tribunal, em seu caso, deverá ratificá-la ou levantá-la num prazo não superior a cinco meses”. 
(salvo a das Ilhas Baleares que não foi impugnada como outras pela óbvia razão de que não compartilha águas fluviais com qualquer Comunidade Autônoma) esteja ainda pendente de solução por parte do Tribunal Constitucional. No momento, as reformas abriram possibilidades de desenvolvimento natural do Estado autonômico, tentando solucionar os problemas que foram surgindo até agora.

Todas estas reformas atingiram, em maior ou menor grau, diversos âmbitos comuns, dentre os quais poderíamos destacar os seguintes: relação com a Europa, competências, mecanismos de relação com o Estado, financiamento, reformas institucionais e aspectos identitários e relativos a direitos. Em todos estes âmbitos produziu-se um debate prévio, de distinta intensidade, em relação às necessidades de reforma estatutária e à possível orientação da reforma.

Os Estatutos anteriores eram (assim como continuam sendo os Estatutos não reformados) textos que haviam dado as costas a muitas coisas. Não que o houvessem feito de maneira consciente, mas no momento em que foram elaborados (pouco depois da aprovação da Constituição de 1978, e num contexto muito diferente do que existe hoje na Espanha do Estado Autonômico já desenvolvido e integrado na União Européia) não haviam incorporado muitas coisas que devem estar nas normas fundamentais de cada Comunidade Autônoma.

Os Estatutos davam as costas a Europa, já que não continham qualquer menção à Europa nem à União Européia. Davam as costas à sociedade, pois se limitavam a regulamentar (com algumas exceções pontuais) a ordenação institucional e o sistema de competências da Comunidade Autônoma. Paradoxalmente, também estavam de costas para sua própria ordenação institucional, porquanto muitas das instituições da Comunidade não haviam se incorporado inicialmente aos Estatutos e o foram fazendo progressivamente através de simples leis autonômicas. O mesmo caberia se dizer das suas competências, posto que muitas delas haviam sido objeto de desenvolvimento e especificação por parte da doutrina do Tribunal Constitucional, porém não estavam incorporadas como tais aos Estatutos. Também davam as costas ao Estado ao não prever mecanismos de relação e coordenação com as instituições gerais do Estado. Davam as costas, igualmente, às outras Comunidades Autônomas e aos entes locais.

Considerando a situação apresentada pelas deficiências dos Estatutos, poderia ser dito que os novos Estatutos possibilitaram um encontro ou um reencontro. Um encontro com a Europa e com a União Européia, que nos permite falar agora de Estatutos europeístas. Um reencontro com a sociedade da Comunidade Autônoma e com os cidadãos, pois os novos Estatutos incorporam referências identitárias e declarações de direitos. Com sua própria organização institucional, pois confere nível estatutário a instituições e técnicas que haviam se desenvolvido fora do Estatuto. Com suas competências, incluindo agora aquelas que o Tribunal Constitucional lhes havia atribuído ao longo do estabelecimento do Estado autonômico. Com o Estado, já que estabelecem mecanismos específicos de relação com as instituições gerais. Também com as outras Comunidades Autônomas. E igualmente com os entes locais, agora regulamentados e em relação aos quais assumem responsabilidade como poder público territorial. 
No entanto, as reformas vieram unidas a um debate político muito intenso e a uma sucessão de recursos ante o Tribunal Constitucional, que terá que decidir, em diversa medida, acerca da constitucionalidade de todas as reformas estatutárias salvo a das Ilhas Baleares (o que se explica, conforme já indicado, porque algumas reformas foram impugnadas só por questões pontuais relativas aos recursos hidráulicos compartilhados entre várias Comunidades Autônomas, o que não afeta as Ilhas Baleares por se tratarem, como a própria denominação indica, de ilhas). O conflito político tem sido tão complexo que os mesmos preceitos estatutários que foram impugnados no caso da Catalunha não sofreram semelhante destino no caso de outros Estatutos de Autonomia.

O receio ante a incorporação do Direito constitucional aos Estatutos, através de um novo modelo de Estatuto integrado por declarações de direitos e uma vinculação específica com os cidadãos, emulando uma formulação constitucional ${ }^{54}$ se explica pelo temor de que este novo modelo de Estatuto contribua a fomentar a qualidade estatal de algumas Comunidades Autônomas favorecendo futuros movimentos independentistas. O temor, em definitivo, de que os territórios ampliem sua base constitucional como estratégia para terminar convertendo-se em Estados. No entanto, estes territórios já têm um espaço constitucional próprio que deve estar sempre submetido à Constituição. Se as Comunidades Autônomas têm governos e parlamentos, se estão dotadas de autonomia política e amplas competências, será sempre positivo que desenvolvam mecanismos constitucionais de controle. Não serão mais "Estado" por causa disso. Que sejam ou não Estado não dependerá de que suas autoridades estejam submetidas a controles constitucionais tão amplos como as do Estado.

Ante este temor, ainda que compreensível, a incorporação de elementos constitucionais aos Estatutos não pode ser entendida como algo negativo. Pelo contrário, a inserção de elementos constitucionais em qualquer dos níveis no contexto de um constitucionalismo multinível representa um elemento positivo que possibilita, em última instância, a formulação de novas garantias, de novos instrumentos de controle do poder e exigência de responsabilidade e da ampliação dos direitos dos cidadãos.

\subsection{As Reformas em Nível Europeu}

O temor à incorporação do Direito constitucional (declarações de direitos, princípios a que se submete o poder público, controles e limitação do poder, em suma) no âmbito infra-estatal, soma-se a um similar receio, por parte de alguns setores, no âmbito europeu. O Projeto de Tratado Constitucional já incorporava múltiplas cautelas em relação à ampliação da base constitucional da União Européia. No entanto, o Projeto de Tratado de Reforma superou todas as expectativas dos chamados "euro-céticos" no que se refere à eliminação de qualquer elemento simbólico que pudesse invocar a imagem de um "Estado" ou "Superestado" europeu.

Assim, eliminou-se o nome "Constituição", assim como os termos "lei européia” ou "lei marco européia”. Igualmente, o princípio de primazia já não será incorporado aos Tratados e sim a um Protocolo. O mesmo cabe dizer da Carta de Direitos

${ }^{54}$ Cfr. S. Muñoz Machado, “El mito del Estatuto-Constitución y las reformas estatutarias”, em Informe Comunidades Autónomas 2004, Instituto de Derecho Público, Barcelona, 2005. 
Fundamentais, que não será incorporada aos Tratados, mas será objeto de uma remissão específica por parte do reformado Tratado da União Européia. No que se refere aos símbolos, a Bandeira ou o Hino já não serão integrados aos Tratados ${ }^{55}$.

Esta ocultação dos elementos simbólicos não tem qualquer valor jurídico específico, por que o conteúdo do Projeto de Tratado Constitucional foi incorporado em mais de $90 \%$ ao Projeto de Tratado de Reforma. É evidente que a eliminação dos aspectos simbólicos de caráter constitucional não priva o Tratado da condição de Constituição. Se a Carta de Direitos Fundamentais estará vigente, se continua havendo uma diferenciação clara entre as competências, se entre atos não legislativos e atos legislativos se estabelece uma distinção (embora estes últimos não se definam como “leis”) se, em definitivo, todos os conteúdos do Tratado anterior são mantidos, caberá se preguntar por qual motivo nós, juristas, o caracterizaremos, agora, de uma maneira distinta. Só porque os Estados signatários agora não chamam de "Constituição” aquilo que assim denominavam anteriormente? Uma Constituição pode deixar de sê-lo porque aqueles que antes a definiram como tal, agora, em face do mesmo conteúdo, a definam de outra maneira?

O que parece claro é que passamos de uma Constituição com forma de Tratado (ou seja, de um Tratado com conteúdo constitucional) a uma Constituição com nome de Tratado. A conclusão à qual podemos chegar não é muito reconfortante: ou antes não se tratava de uma Constituição e haviam tentado fazer passar por tal o que não o era, ou agora tentam fazer passar por um mero Tratado aquilo que de fato trata-se de uma Constituição. Por que o que temos que descartar, em todo caso, é que o mesmo conteúdo constitucional possa ser e não ser uma Constituição ao mesmo tempo. A política, inclusive a européia, não pode chegar a tanto.

Na realidade, o Conselho Europeu de Bruxelas de 21 e 22 de Junho de 2007 realizou apenas algumas "precisões" no conteúdo do Tratado Constitucional estabelecido pela CIG de 2004. De acordo com as Conclusões da Presidência, a primeira delas afeta a forma, já que agora não teremos um único Tratado que revogue todos os anteriores. Pelo contrário, teremos um primeiro Tratado, o Tratado de Reforma, com duas cláusulas substantivas que modificarão respectivamente o Tratado da União Européia (TUE) e o Tratado constitutivo da Comunidade Européia (TCE). Este último mudará de nome e passará a se chamar "Tratado sobre o funcionamento da União". Se por um lado os Tratados não são unificados, por outro é atribuída personalidade jurídica única à União Européia, que passa a substituir e suceder a Comunidade. A palavra “Comunidade” será sustituída em todo o texto por "União”, e será estipulado que ambos os Tratados constituem aqueles sobre os quais está fundada a União e que esta substitui e sucede a Comunidade. É evidente, em todo caso, que uma Constituição não tem que estar contida num único texto, razão pela qual o fato de que não haja mais um único Tratado não afeta a natureza constitucional do conteúdo dos Tratados.

Além destas questões puramente formais, o Anexo I das Conclusões da Presidência contém outras especificações em relação ao anterior Projeto de Tratado Constitucional.

\footnotetext{
${ }^{55}$ Sobre a importância que têm estas questões, cfr. Peter Häberle, Nationalhymnen als kulturelle Identitätselemente des Verfassungsstaates, Duncker \& Humblot, Berlin, 2007.
} 
Assim, no seu parágrafo $3^{\circ}$ se indica que:

“O TUE e o Tratado sobre o funcionamento da União não terão caráter constitucional. A terminologia utilizada em ambos os Tratados expressará esta mudança: não será utilizado o termo "Constituição", o "Ministro de Assuntos Exteriores da União” passará a se chamar Alto Representante da União para Assuntos Exteriores e Política de Segurança e serão abandonadas as denominações "lei" e "lei marco", sendo conservadas as atuais de "regulamento" "diretiva" e “decisão". Do mesmo modo, não figurará nos Tratados modificados qualquer artigo que mencione os símbolos da UE (bandeira, hino ou divisa). Enquanto à primazia do Direito da UE, a CIG adotará uma declaração na qual se recorde a jurisprudência existente do Tribunal de Justiça da UE”.

Estas especificações são expressão do medo ao Direito constitucional ao qual fizemos referência anteriormente. No entanto, não cumprem a função para a qual foram elaboradas: a de desnaturalizar a entidade constitucional da reforma dos Tratados. Assim, quando se indica que "O TUE e o Tratado sobre o funcionamento da União não terão caráter constitucional" afirma-se algo que, além de contradizer a jurisprudência do Tribunal de Justicia (Sentença de 23 de abril de 1986, assunto 294/83, Os Verdes v. Parlamento, ap. 23), não tem qualquer sustentação argumentativa nas seguintes afirmações:

1. "Não se utilizará o termo Constituição". Para salientar um exemplo ilustre, a Constituição alemã se auto-denomina "Lei Fundamental" sem que ninguém negue seu caráter constitucional.

2. "O "Ministro de Assuntos Exteriores da União" passará a se chamar Alto Representante da União para Assuntos Exteriores e Política de Segurança”. Esta especificação não merece qualquer comentário em relação a qualquer possível incidência no valor constitucional dos Tratados reformados.

3. "Serão abandonadas as denominações "lei" e "lei marco", conservando-se as atuais de "regulamento" "diretiva” e "decisão”". Esta precisão tampouco tem qualquer incidência material. O próprio Anexo I se ocupa em esclarecer este aspecto mais adiante. Assim, no parágrafo 19 v) do Anexo I se indica que:

"Como conseqüência do abandono da denominação "lei" e "lei marco", as inovações acordadas na Conferência Inter-governamental de 2004 serão adaptadas do modo correspondente, mantendo-se a distinção entre o que é e o que não é um ato legislativo, assim como suas conseqüências. Por conseguinte, depois do artigo 249, serão acrescentados três artigos relativos, respectivamente, aos atos adotados em conformidade com um procedimento legislativo, os atos delegados e os atos de execução. O artigo sobre os atos legislativos estabelecerá que serão atos legislativos todos aqueles atos (regulamentos, diretivas ou decisões) adotados em relação a um procedimento legislativo (seja ordinário ou especial). A terminologia dos artigos relativos aos atos delegados e aos atos de execução, acordada na Conferência Intergovernamental de 2004, será adaptada como conseqüência”. 
A diferenciação entre atos legislativos e não legislativos, como se pode ver, é mantida. Não podia ser de outro modo caso se queira dar valor jurídico à Carta de Direitos Fundamentais e aos outros parágrafos nos quais estão contidas reservas de lei. Assim, pois, continuarão existindo reservas de lei enquanto reservas de atos legislativos e diferenciação entre atos legislativos e atos não legislativos. De acordo com o Projeto de Tratado de Reforma, de 23 de Julho de 2007, o artigo 249 A.3 do atual Tratado sobre o funcionamento da União, estabelece que serão atos legislativos os atos jurídicos adotados mediante um procedimento legislativo. A única especificação é de que os atos legislativos não serão denominados leis, o que revela coerência (desgraçadamente) com o fato de que os atos constitucionais tampouco se chamem Constituição.

4. "Não figurará nos Tratados modificados qualquer artigo que mencione os símbolos da UE (bandeira, hino ou divisa)”. Como se pode ver, não se trata de que os símbolos não existam nem deixem de ser símbolos da União. A redação deixa bem claro que estes são os símbolos da UE, só que não serão mencionados em nenhum artigo dos Tratados.

5. "No que concerne à primazia do Direito da UE, a CIG adotará uma declaração na qual se mencione a jurisprudência existente do Tribunal de Justiça da UE”. No rodapé da página se indica que "Embora o artigo sobre a primazia do direito da União não se reproduza no TUE, a CIG acordará a seguiente Declaração: A Conferência recorda que, em consonância com a jurisprudência reiterada do Tribunal de Justiça da UE, os Tratados e a legislação adotada pela União sobre a base dos Tratados primarão sobre o direito dos Estados-membros, em conformidade com as condições estabelecidas pela citada jurisprudência". Esta formulação foi incorporada à Declaração 29 do Projeto de Declarações de 23 de julho de 2007.

A incorporação do princípio de primazia ao Tratado Constitucional não modificava a situação jurídica precedente, razão pela qual tampouco esta especificação supõe qualquer modificação que afete o valor do princípio de primazia nem o caráter constitucional da reforma. De fato, o Parecer do Serviço Jurídico do Conselho de 22 de Junho de 2007, cuja incorporação à Ata Final da Conferência está prevista, indica claramente que o fato de que a primazia não se inclua no futuro Tratado não modifica, em nada, a existência deste princípio nem a jurisprudência do Tribunal de Justiça em vigor.

O parágrafo 4 do Anexo I reitera que "No que concerne ao conteúdo das modificações dos atuais Tratados, as novidades resultantes da CIG de 2004 serão integradas ao TUE e ao Tratado sobre o funcionamento da União, tal como especificadas no presente mandato". Estas novidades contêm algumas especificações que, do ponto de vista constitucional, não têm grande relevância (o que não quer dizer que não sejam importantes partindo de outras perspectivas). A de maior importância, que segue a linha já traçada em relação ao termo "Constituição", os termos "lei” e "lei marco" e o princípio de primazia, é a referida à Carta de Direitos Fundamentais. A situação jurídica da Carta de Direitos Fundamentais será a de uma Carta com o mesmo valor que os Tratados, embora não incorporada a estes. De acordo con o que indica o parágrafo 9 do Anexo I: 
“O artigo relativo aos direitos fundamentais conterá uma referência cruzada à Carta dos Direitos Fundamentais, tal como foi aprovada na CIG de 2004, que lhe conferirá um caráter jurídico vinculante e estabelecerá seu âmbito de aplicação”. Em nota de rodapé se esclarece que "Por conseguinte, não se incluirá nos Tratados o texto da Carta dos Direitos Fundamentais". No próprio Anexo I se esclarece, mais adiante, a formulação concreta que deverá conter o preceito, ao se indicar em sua epígrafe 5), dentro do parágrafo sobre as modificações do Tratado da União Européia, que:

“5) O artigo 6 sobre os direitos fundamentais será substituído pelo seguinte texto: 1. A União reconhece os direitos, liberdades e princípios enunciados na Carta dos Direitos Fundamentais de 7 de dezembro de 2000, tal como foi adaptada no [... de 2007], que terá o mesmo valor jurídico que os Tratados.

As disposições da Carta não ampliarão de modo algum as competências da União tal como se definem nos Tratados.

Os direitos, liberdades e princípios da Carta serão interpretados de acordo com as disposições gerais do título VII da Carta através das quais se rege sua interpretação e aplicação, e levando devidamente em conta as explicações às quais se faz referência na Carta, que indicam as fuentes de ditas disposiciones.

2. A União se aderirá ao Convênio Europeu para Proteção dos Direitos Humanos e das Liberdades Fundamentais. Esta adesão não modificará as competências da União definidas nos Tratados.

3. Os direitos fundamentais garantidos pelo Convênio Europeu para Proteção dos Direitos Humanos e das Liberdades Fundamentais e os que são fruto das tradições constitucionais comuns aos Estados-membros fazem parte do Direito da União como princípios gerais”.

A versão da Carta em relação à qual se produzirá a remissão será, conforme indicado na nota 21 do Anexo I, a contida no Tratado Constitucional que, como tal, será publicada no Diário Oficial da União Européia.

A especificação do “caráter jurídico vinculante” da Carta, “a qual terá o mesmo valor jurídico que os Tratados”, elimina qualquer dúvida sobre sua natureza constitucional. A perplexidade que pode produzir o fato de que não se incorpore aos Tratados - justamente pela nula relevância jurídica desta não incorporação - não invalida, em absoluto, a esta consideração.

Não obstante, por mais que o conteúdo do Projeto de Tratado Constitucional entre em vigor em mais de $90 \%$, não podemos ignorar o sentido que têm as reticências de alguns Estados aos símbolos constitucionales. Reticências que foram admitidas pelos demais Estados e que são expressão de um medo ao Direito constitucional em nível europeu que soa surpreendente quando contrastado com o nível estatal.

Por outro lado, tampouco podemos ignorar as dificuldades atuais de adoção de novas decisões constitucionais na União Européia, do que em termos internos é reforma constitucional e no âmbito da União Européia ainda continua sendo revisão de Tratados, submetida a um principio de unanimidade dos Estados-membros da União Européia. Este princípio de unanimidade supõe uma dificuldade adicional às 
reformas pois continua baseando as decisões fundamentais nos Estados-membros, mediante técnicas supranacionais, ao invés de situá-las nos cidadãos através de mecanismos constitucionais. É uma confirmação a mais de que a União Européia foi, até sua formulação atual, um instrumento útil para que os Estados pudessem afrontar a globalização e os processos de descentralização territorial. Utilidade que, hoje em dia, é mais que questionável ante os desafios que a União Européia tem que afrontar no contexto mundial.

7.3. A centralidade do nível estatal. As reservas estatais ao crescimento do Direito constitucional europeu e do Direito autonômico

Temos, no âmbito específico dos Direitos fundamentais, um exemplo das reservas do Estado ante o crescimento do nível constitucional europeu e dos autonômicos. O nível estatal é, na atualidade, o único no qual existe uma plenitude de instâncias e agentes que interagem no processo de prefiguração e configuração de Direitos fundamentais que indiscutivelmente se manifestam como tais. Certo é, no entanto, que a elaboração e proclamação da Carta dos Direitos Fundamentais da União Européia de Nice (2000) e sua prevista capacidade de vinculação jurídica (inicialmente no Projeto de Tratado Constitucional e atualmente no Tratado de Reforma) supõe um impulso importante à consolidação de um sistema de direitos no nível europeu. O mesmo se pode dizer das últimas reformas dos Estatutos de Autonomia na Espanha, que deram ensejo à incorporação de Cartas de Direitos que não existiam anteriormente.

No entanto, o Estado espanhol contribuiu -juntamente com os demais Estadosmembros da UE- para a formulação de importantes cautelas na Carta dos Direitos Fundamentais que permitem salvaguardar seu papel essencial de regulador dos Direitos. Ocorreu o mesmo, no caso da Espanha, no aspecto territorial, através de similares cautelas incorporadas aos novos Estatutos de Autonomia.

Partindo do Direito europeu, a Carta deixa bem claro que o Estado continua sendo o regulador essencial dos Direitos. Concentrando-nos tão só nos aspectos mais destacados das cautelas incorporadas a favor dos Estados, podemos mencionar o art. $111^{56}$ que contém uma limitação competencial relativa aos direitos constante da Carta:

“1. As disposiçõe da presente Carta estão dirigidas às instituições, órgãos e organismos da União, dentro do respeito ao princípio de subsidiariedade, assim como aos Estados-membros unicamente quando apliquem o Direito da União. Por conseguinte, estes respetarão os direitos, observarão os princípios e promoverão sua aplicação, em atenção a suas respectivas competências e dentro dos limites das competências atribuídas à União nas demais Partes da Constituição.

2. A presente Carta não amplia o âmbito de aplicação do Direito da União além das competências da União, nem cria qualquer competência ou missão novas para a União, nem modifica as competências e missões definidas nas demais Partes da Constituição”.

\footnotetext{
${ }^{56}$ Citamos os artigos do Tratado Constitucional, na versão que será vinculante, ainda que varie a numeração dos artigos.
} 
Por outro lado, ainda no âmbito do Direito europeu, no artigo 113 (na versão da Carta do Tratado Constitucional) se estabelece que: "Nenhuma das disposições da presente Carta poderá ser interpretada como limitadora ou lesiva aos direitos humanos e liberdades fundamentais reconhecidas, no seu respectivo âmbito de aplicação, pelo Direito da União, o Direito internacional e os convênios internacionais dos quais são parte a União ou todos os Estados-membros, e em particular o Convênio Europeu para Proteção dos Direitos Humanos e das Liberdades Fundamentais, assim como pelas constituições dos Estados-membros”.

Estes dois preceitos da Carta que supõem, por um lado a limitação dos direitos ao âmbito das competências da União, e por outro, o respeito aos padrões estabelecidos nas Constituições dos Estados-membros, foram incorporados aos novos Estatutos de Autonomia no atual processo de reformas territoriais na Espanha.

Assim, o artigo 13 do novo Estatuto da Andaluzia indica no seu primeiro parágrafo que "Os direitos e princípios do presente Título não implicarão uma alteração do regime de distribuição de competências, nem a criação de títulos competenciais novos ou modificação dos já existentes”. Por sua parte, o segundo parágrafo dispõe que "Nenhum dos direitos ou princípios contemplados neste Título pode ser interpretado, desenvolvido ou aplicado de modo a limitar ou reduzir direitos ou princípios reconhecidos pela Constituição ou pelos tratados e convênios internacionais ratificados pela Espanha”. Preceitos similares se encontram (salvo no caso da Comunidade Valenciana) nos demais Estatutos que foram objeto de reforma ${ }^{57}$.

Trata-se, sem dúvida, de um exemplo claro das teorias de Peter Häberle relativas ao paradigma do gradativo desenvolvimento dos textos constitucionais ${ }^{58}$. Porém, ao mesmo tempo, estes preceitos europeus e autonômicos são expressão da vontade do Estado de seguir sendo o âmbito constitucional de regulação dos direitos fundamentais, no contexto dos processos de integração européia e de descentralização territorial. Somente no nível estatal se produz uma ordenação dos direitos que integra, em plenitude, a interação entre o constituinte (em referência a autênticos Direitos fundamentais),

57 Assim, o Estatuto da Catalunha indica no seu artigo 37.4 que: "Os direitos e princípios do presente Título não implicarão uma alteração do regime de distribuição de competências, nem a criação de títulos competenciais novos ou a modificação dos já existentes. Nenhuma das disposições deste Título pode ser desenvolvida, aplicada ou interpretada de forma que reduza ou limite os direitos fundamentais reconhecidos pela Constituição e pelos tratados e convênios internacionais ratificados pela España”. Igualmente, no Estatuto das Ilhas Baleares, em seu artigo 13.3 se estabelece que: "Os direitos e princípios do presente Título não implicarão alteração do regime de distribuição de competências, nem a criação de títulos competenciais novos ou a modificação dos já existentes. Nenhuma das disposições deste Título pode ser desenvolvida, aplicada ou interpretada de forma que reduza ou limite os direitos fundamentais reconhecidos pela Constituição e pelos tratados e convênios internacionais ratificados pela Espanha”. Tambén no de Aragão, no seu artigo 6.3: “Os direitos e princípios do Título I deste Estatuto não implicarão uma alteração do regime de distribuição de competências, nem a criação de títulos competenciais novos ou a modificação dos já existentes. Nenhuma de suas disposições pode ser desenvolvida, aplicada ou interpretada de forma que reduza ou limite os direitos fundamentais reconhecidos pela Constituição e pelos tratados e convênios internacionais ratificados pela Espanha”.

${ }^{58}$ Cfr. Peter Häberle, “Textstufen als Entwicklungswege des Verfassungsstates”, 1989, en la recopilación del mismo autor Rechtsvergleichung im Kraftfeld des Verfassungsstaates. Methoden und Inhalte, Kleinstaaten und Entwicklungsländer, Duncker \& Humblot, Berlín, 1992, pp. 3-26. 
o legislador e a jurisdição. Esta plenitude é coerente com a existência de um espaço público consolidado, de um nível de decisão constitucional estável e de uma comunidade política desenvolvida. É previsível, no entanto, uma evolução futura orientada ao desenvolvimento do nível europeu e do nível autonômico. Este desenvolvimento permitirá uma interação mais intensa entre os diversos níveis e espaços constitucionais e novos progressos na configuração dos Direitos fundamentais.

\section{CONCLUSÕES}

A primeira reflexão que temos que realizar ao analisar as possibilidades e os limites da reforma constitucional na Espanha, é de caráter metodológico: posto que a “matéria constitucional” não se encontra, hoje em dia, somente na Constituição de 1978, de "reforma constitucional" não se pode falar unicamente em referência ao texto da Constituição de 1978. Esta é uma conseqüência do pluralismo ordenamental ao qual a Constituição espanhola se abre num contexto de constitucionalismo multinível, de diversidade de espaços constitucionais.

A partir desta reflexão, podem ser determinados com mais clareza os limites da reforma. Com efeito, a fragmentação da matéria constitucional significa também a fragmentação do poder constituinte, que implica limites específicos à reforma. Estes limites se manifestam em todos os níveis constitucionais. No europeu evidenciam-se nas cláusulas de salvaguarda da identidade constitucional dos Estados (contidas previamente no artigo I-5.1 do Tratado Constitucional e agora no artigo 4.2 TUE, de acordo com o Projeto de Tratado de Reforma de 23 de Julho de 2007). No autonômico, no caso da Espanha, os Estatutos de Autonomia têm como limite infranqueável o texto constitucional, que deve ser respeitado por qualquer reforma estatutária. No estatal, também no caso da Espanha, embora estes limites não estejam expressamente contemplados, decorrem dos processos de integração européia e de descentralização territorial, razão pela qual são hoje operativos em nível autonômico e europeu. A Constituição já não pode ser reformada num sentido contrário ao Estado autonômico ou à União Européia.

Partindo também da diversidade de níveis constitucionais podemos compreender melhor as possibilidades da reforma em relação às necessidades constitucionais dos distintos níveis. Para tanto, temos que levar em conta a relação dialética gerada entre os diversos níveis ordenamentais e as necessidades de reforma que esta relação dialética origina. Num sistema de pluralismo ordenamental, facilitar a reforma das normas fundamentais é algo necessário para que a interação entre os diversos ordenamentos possa funcionar de maneira eficaz. No entanto, não é esta a situação atual na Espanha, onde a própria regulamentação da reforma constitucional evidencia, no seu procedimento agravado, a enorme dificultade para a realização das reformas constitucionais.

As dificuldades procedimentais para a reforma do texto constitucional na Espanha seriam contornáveis se houvesse consenso entre governo e oposição. No entanto, à complicada regulamentação procedimental une-se o receio de que a reforma gere polêmicas territoriais que debilitem o Estado em favor das Comunidades Autônomas. Este tem sido o motivo fundamental que impede até agora o acordo entre governo e oposição. Porém, ao mesmo tempo, este receio foi transferido às recentes reformas estatutárias, dando lugar a intensas polêmicas. 
No âmbito europeu, por seu turno, apesar de que a Espanha defenda uma forte posição europeísta (a Espanha aprovou em referendo a ratificação do Projeto de Tratado Constitucional, em 20 de fevereiro de 2005) não se pode ignorar que existe também uma grande dificultade para avançar em direção a um modelo de reforma constitucional que supere o atual sistema de revisão dos Tratados, baseado na unanimidade dos Estados-membros.

Por outro lado, é constatável o receio de muitos setores políticos ao avanço do Direito constitucional no âmbito da União Européia e, no caso da Espanha, no âmbito das Comunidades Autônomas. Este receio se deve à consideração do Direito constitucional como um fator "performativo" da qualidade estatal dos ordenamentos. Estes setores se esquecem, no entanto, da importante função desenvolvida pelo Direito constitucional enquanto instrumento de controle do poder público, de submissão dos poderes públicos à responsabilidade e de garantia dos Direitos dos cidadãos.

Frente a este temor ao Direito constitucional, cabe considerar que a interação entre os diversos níveis constitucionais no contexto do constitucionalismo multinível na Europa deve ser um fator poderoso de desenvolvimento do Direito Constitucional. Como tal, pode contribuir, mediante uma maior flexibilização dos procedimentos de reforma em cada nível, para favorecer novos progressos do constitucionalismo na melhoria dos mecanismos de controle do poder e de ampliação dos direitos dos cidadãos. 